\title{
14. HIGH-RESOLUTION STUDY OF NEOGENE ICE-RAFTED DEBRIS, SITE 751, SOUTHERN KERGUELEN PLATEAU1
}

\author{
James R. Breza ${ }^{2}$
}

\begin{abstract}
One of the primary objectives of Leg 120 was to obtain a high-resolution Neogene stratigraphic section from the Kerguelen Plateau. Site 751, located in the central part of the Raggatt Basin on the Southern Kerguelen Plateau in $1633.8 \mathrm{~m}$ of water $\left(57^{\circ} 43.56^{\prime} \mathrm{S} ; 79^{\circ} 48.89^{\prime} \mathrm{E}\right.$ ) (Fig. 1), was selected as the dedicated Neogene site for this objective. High-resolution sampling at Site 751 was used to delineate in detail the Neogene ice-rafted debris (IRD) occurrences on the Kerguelen Plateau.

The oldest IRD found at Site 751 was approximately $9.9 \mathrm{Ma}$, and it was not until approximately 8.5 Ma that significant concentrations of IRD were detected. The first major IRD event at this site occurred in the uppermost Miocene between 6.0 and 5.5 Ma. During this time period, a general climatic cooling and glacial expansion occurred on Antarctica.

The late Miocene IRD event was followed by a continuous episode of elevated IRD deposition in the lowermost Pliocene between 4.5 and 4.1 Ma. The 0.4-m.y. duration and the timing of the early Pliocene IRD event on the Kerguelen Plateau corresponds with IRD fluxes observed on the Falkland Plateau and in the Weddell Abyssal Plain. This correspondence of data indicates that a major global climatic event occurred during the early Pliocene. The East Antarctic Ice Sheet may have experienced deglaciation between 4.5 and $4.1 \mathrm{Ma}$ and, as a result, released large volumes of sediment-laden ice into the Southern Ocean.
\end{abstract}

\section{INTRODUCTION}

One of the primary objectives of Leg 120 was to obtain a high-resolution Neogene stratigraphic section from the Kerguelen Plateau. Site 751, located in the central part of the Raggatt Basin on the Southern Kerguelen Plateau in $1633.8 \mathrm{~m}$ of water $\left(57^{\circ} 43.56^{\prime} \mathrm{S} ; 79^{\circ} 48.89^{\prime} \mathrm{E}\right.$ ) (Fig. 1), was selected as the dedicated Neogene site for this objective. Several features make this site suitable for the study of ice-rafted debris (IRD): (1) high sedimentation rates in the Miocene-Pliocene portion of the section, (2) variable physical and sedimentological properties, and (3) the ideal physiographic setting of the Kerguelen Plateau.

The geographic isolation of the Kerguelen Plateau provided an ideal setting for the study of the Neogene IRD record in this portion of the Southern Hemisphere. The plateau is a structural high isolated from any continental input via turbidities or nepheloid transport (Fig. 1). It is bounded to the northeast by the Australian-Antarctic Basin, to the southwest by the African-Antarctic Basin, and to the northwest by the Crozet Basin. To the south it is separated from Antarctica by the Princess Elizabeth Trough. This isolation makes it probable that any nonvolcaniclastic debris found in the Neogene sediments at this site would be of ice-rafted origin.

The physiographic setting of Site 751 on the Kerguelen Plateau is somewhat similar to that of the Maurice Ewing Bank on the Falkland Plateau. Both sites are located on submerged aseismic structural highs and are far removed from any direct continental influence. In his study of IRD on the Maurice Ewing Bank of the Falkland Plateau, Bornhold (1983) was able to exclude the effects of transportation of clastic material by wind, turbidities, and bottom-water currents based on the physio-

\footnotetext{
${ }^{1}$ Wise, S. W., Jr., Schlich, R., et al., 1992. Proc. ODP, Sci. Results, 120: College Station, TX (Ocean Drilling Program).

2 Department of Geology, Florida State University, Tallahassee, FL 32306 , U.S.A.
}

graphic makeup of the plateau. Similarly, the isolation of the Kerguelen Plateau constrains many of the variables of terrigenous sedimentation that could otherwise hide or skew the IRD record. Thus, in this study all clastic sands and gravels that are clearly not of volcanic origin are assumed to have originated by ice-rafting.

The IRD in the Neogene deep-sea sedimentary record may be related to the rate of ice-volume changes on Antarctica. Some investigators have suggested that certain IRD maxima can be associated with interglacial periods (Denton et al., 1971; Anderson, 1972; Keany et al., 1976). This occurs when climatic warming causes a reduction of ice shelves and subsequently results in the increase of iceberg calving, delivering sediment-laden icebergs directly to the open ocean. Warnke (1970) suggested that the amount of terrigenous debris found in icebergs can vary, depending on the stage of the glacial erosional cycle involved. The greatest IRD flux occurs when the ice sheet is first established. Thus, toward the end of a glacial cycle, less debris would be available for glacial transport because most of the loose, unconsolidated material would have been scraped up and removed by the ice. During an interglacial period, more debris could be generated as the result of subaerial weathering of the exposed bedrock surface, thus establishing a new source of easily erodible material for the next glacial cycle. Regardless of the timing of any IRD event, the IRD signals in the deep-sea sediments are records of significant changes in Antarctica's climate.

Ice volume changes may also be detected in the geochemical record. Investigators such as Shackleton and Kennett (1975), Miller et al. (1987), and Shackleton (1987) observed significant changes in the Neogene deep-sea stable isotopic record. They interpret these changes as recording global fluctuations in atmospheric and oceanic temperatures and in continental ice volumes. These measurements do not provide direct physical evidence of climatic changes. However, Bornhold (1983) suggests that the most graphic evidence of severe climatic changes in high-latitude sediments can be demonstrated by variations in the concentration of IRD. 


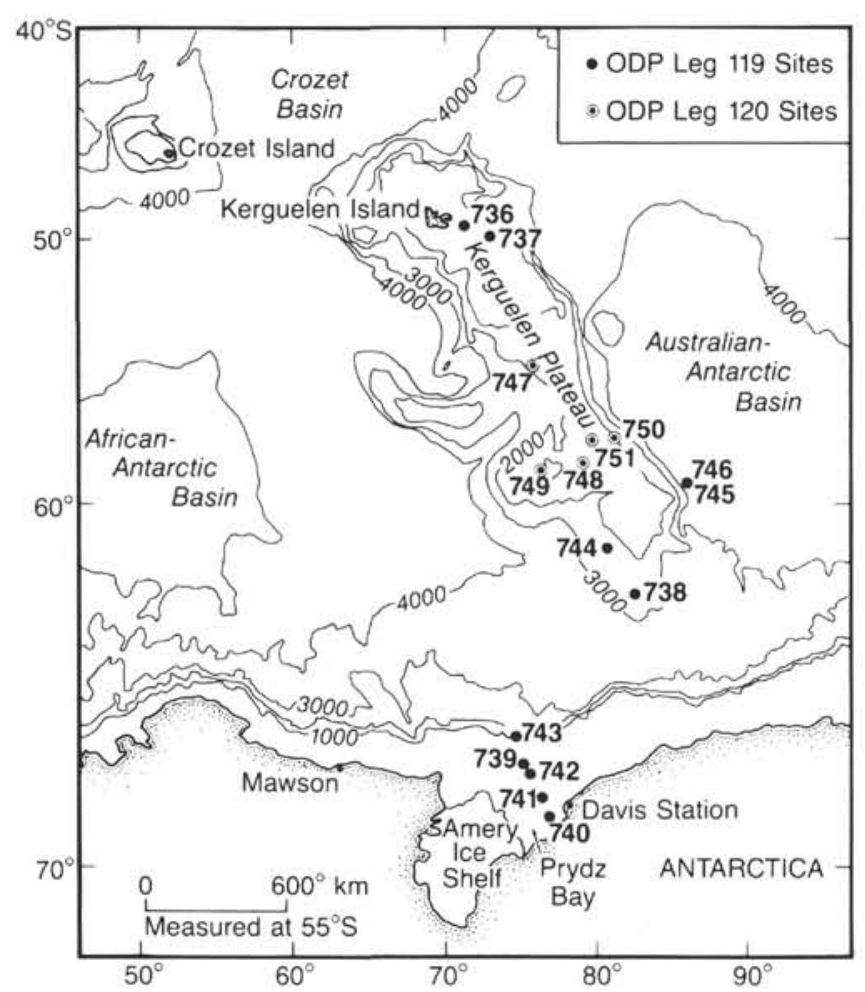

Figure 1. Bathymetric chart of the Kerguelen Plateau showing the locations of Leg 120 sites and previously drilled Leg 119 sites in Prydz Bay.

The purpose of this paper is to delineate in detail IRD occurrences on the Kerguelen Plateau and to use the variations in IRD as indicators of Neogene Antarctic glacial activity. The study (1) describes fluctuations in the concentration and composition of IRD in upper Miocene to Pleistocene sediments, (2) relates these observations to other records of high southern latitude IRD occurrences, and (3) relates these observations to paleoclimatic changes.

\section{LITHOSTRATIGRAPHY}

Site 751 consists of two lithologic units (Fig. 2). Unit I is composed of $40 \mathrm{~m}$ of upper Pleistocene to lower Pliocene diatom ooze with varying amounts of IRD and foraminifers. Unit II consists of $126 \mathrm{~m}$ of upper to lower Miocene diatom nannofossil ooze, with nannofossils as the primary sedimentary component.

Lithologic Unit I (Fig. 2) is a 40 -m section composed of diatom ooze with minor amounts of IRD, foraminifers, volcanic ash, and porcellanitic chert. The ooze is mostly tan or pale brown to cream white and light gray in color. These color changes indicate pelagic variability on scales of $<1 \mathrm{~m}$, which reflects the increased and decreased abundance of siliceous and calcareous microfossils. Porcellanitic chert occurs in Cores 120-751A-2H-CC and 120-751A-3H-1, 0-44 cm. Porcellanitic cherts of Pliocene age were also found on the Kerguelen Plateau in Eltanin Core 47-15 (Wise and Weaver, 1974). The IRD is scattered throughout Unit I in minor abundance, and dropstone occurrences are rare and isolated. The main biogenic component are fossil diatoms, which make up about $90 \%$ of the sediment throughout lithologic Unit I. Short intervals appear to be composed of nearly pure diatoms, giving the appearance of "cotton" (see Rack and Julson, this volume, Chapter 13). Nannofossils are almost absent and foraminifers are common as calcareous debris. Radiolarians are present in abundances of $2 \%-12 \%$. Silicoflagellate abundance is estimated as $1 \%-10 \%$.

Lithologic Unit II (Fig. 2) consists of diatom nannofossil ooze. The sediments are a nearly uniform white to light gray in color. The IRD abundance is at trace amounts in the uppermost Miocene portion of this unit.

\section{ICE-RAFTED DEBRIS INVESTIGATIVE APPROACH}

\section{Spatial Sampling Strategy}

During the Leg 120 cruise, I collected 392 samples from 0 to $90 \mathrm{mbsf}$ in Cores $120-751 \mathrm{~A}-1 \mathrm{H}$ through $-10 \mathrm{H}$ at $20-\mathrm{cm}$ intervals. Samples were not collected between the intervals of 23.7 and 25.9 mbsf and 61.7 and 63.4 mbsf because high drilling disturbance impugned the reliability of the sediment contained between the intervals. The sampling frequency for the IRD analyses varies markedly from 12,000 to $80,000 \mathrm{yr}$ because of variations in sedimentation rates. Sedimentation rates for Site 751 are based on both paleomagnetic and diatom-stratigraphic data (see Harwood and Maruyama, this volume, Chapter 38). The sampling frequency was designed to provide high-resolution coverage for this Neogene section, allow documentation of the occurrence of ice-rafting, and supply sufficient data for interpreting the timing of the icerafting events.

\section{Ice-rafted Debris Index}

The $\geq 250-\mu$ m-diameter clastic fraction was selected as the ice-rafting event index. This size fraction is assumed to be of ice-rafted origin because (1) the presence of windblown material $\geq 250 \mu \mathrm{m}$ in diameter at any appreciable distance from a source area is unlikely (Kent et al., 1971), and (2) transport of this size material by turbidity flow is not considered a factor because of the shallow depths $(1634 \mathrm{~m})$ of the drill site and the isolated location of the Kerguelen Plateau. It is plausible that the plateau could receive volcanic turbidities from Kerguelen Island or calciturbidities from shallow carbonate platform flanks, however, no such material has been identified in the Leg 120 material.

The most commonly used methods to derive an ice-rafted index or to determine the distribution of IRD for the very fine to fine sand fraction ( $\geq 62 \mu \mathrm{m}$ to $<250 \mu \mathrm{m}$ ) are (1) to calculate the weight percent of the total clastic components or (2) to calculate the percent clastic components from a point count of a set number of grains (Kent et al., 1971; Margolis and Kennett, 1971; Keany et al., 1976; Bornhold, 1983; Anderson, 1985). However, the present study uses a different and more precise method as described by Kennett and Brunner (1973) to determine the ice-rafted index, that is, counting the entire suite of clastic grains present in the medium to very coarse sand fraction ( $\geq 250 \mu \mathrm{m}$ to $<2 \mathrm{~mm}$ ), expressed as grains per gram.

\section{Ice-rafted Debris Apparent Accumulation Rate}

The IRD index is adjusted for sedimentation rates and density contrast between constituents to provide an approximate accumulation rate for the IRD material $\geq 250 \mu \mathrm{m}$ to $<2$ $\mathrm{mm}$. The apparent accumulation rate equation used in this study was modified from Keany et al. (1976). Keany et al. (1976) use the term "apparent" to reflect possible natural processes that may distort the measured accumulation rates, such as subtle, undefinable changes in sedimentation rate and large contrasts in density between constituents. IRD accumulation rates were computed by using the equation:

$$
R=N / D \times S,
$$




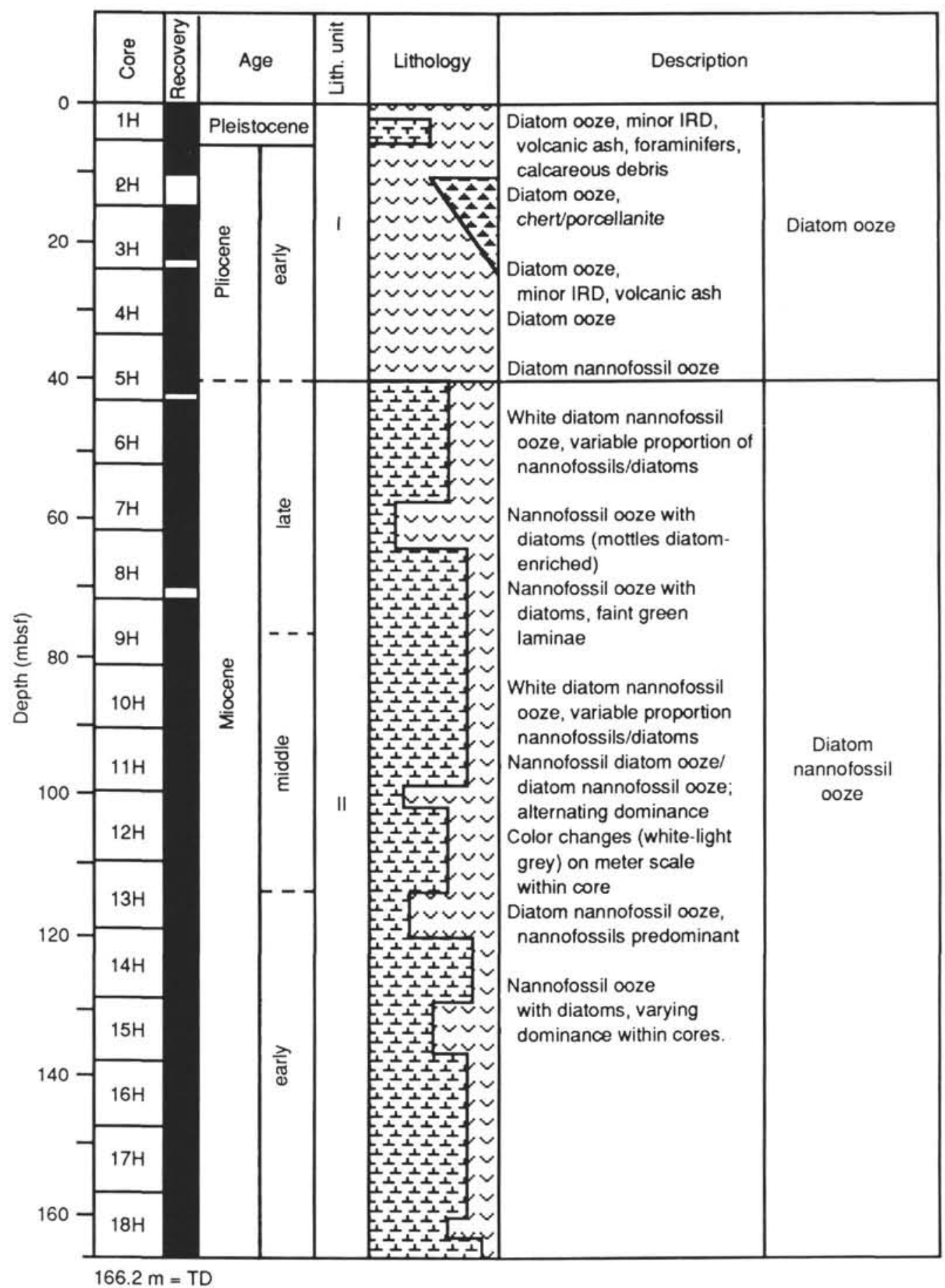

Figure 2. Lithostratigraphy of Site 751, Raggatt Basin, Southern Kerguelen Plateau. Recovered intervals are indicated by shading in the recovery column. For a key to the patterns in the lithology column, see Schlich, Wise, et al. (1989), "Explanatory Notes" chapter. Figure from Schlich, Wise, et al. (1989). IRD = ice-rafted debris and TD $=$ total depth.

where $\mathrm{R}=$ apparent accumulation rate,

$N=$ number of grains per gram of dry-bulk sample,

$D=$ dry-bulk density, and

$S=$ sedimentation rate.

The apparent accumulation rates are expressed as grains per square centimeter per $1000 \mathrm{yr}$. This method of calculating apparent accumulation rates has the following advantages: (1) it overcomes most of the distortion inherent in presenting data in the percentage format, and (2) it incorporates changes in sedimentation rates that can either dilute or concentrate the estimates of IRD occurrence.

The number of grains per gram of dry-bulk sample $(N)$ is determined by dividing the total number of IRD grains counted in the sample by the dry weight of that sample (combined weights of the $<62 \mu \mathrm{m}$ and $\geq 62 \mu \mathrm{m}$ size fractions). The sedimentation rates $(S)$ for Site 751 are based on both 
paleomagnetic and diatom-stratigraphic data (see Harwood and Maruyama, this volume, Chapter 38).

Dry-bulk density $(D)$ measurements were not determined for each sample. However, dry-bulk density values were estimated for each sample by averaging intervals of shipboardderived dry-bulk density measurements. These intervals were statistically grouped by the lowest relative standard deviation achievable (RSTD) (Appendix B, on microfiche in back pocket). The average dry-bulk density value derived for each interval was used in the computation of apparent accumulation rates.

\section{Methods}

Samples ranging in size from 10 to $20 \mathrm{~cm}^{3}$ were disaggregated by soaking them in distilled water for $24 \mathrm{hr}$. They were then dried, weighed, and washed through $250-\mu \mathrm{m}$ and $62-\mu \mathrm{m}$ mesh sieves using distilled water. The $<62-\mu \mathrm{m}$-size fraction was reserved for X-ray diffraction (XRD) analysis of the clay-sized material (see Breza, this volume, Chapter 12). Each sieved sand fraction was then dried and weighed (Appendix A, on microfiche in back pocket). The pebblesized fraction ( $\geq 2 \mathrm{~mm}$ ) was measured and described. The composition of the medium to very coarse fraction $(\geq 250$ $\mu \mathrm{m}$ to $<2 \mathrm{~mm}$ ) was examined under a binocular microscope, and all clastic, volcanic glass, and authigenic components were identified and counted. Volcanic glass was assumed to be from ash fall and was not considered as IRD. Clastic components were grouped into four categories: (1) quartz, (2) feldspar, (3) accessory minerals, and (4) rock fragments. Total clastic components were normalized to the total drybulk weight of the sample (number of grains per gram). Biogenic components of this size fraction were not analyzed. Clastic, authigenic, volcanic glass, and biogenic components in the very fine to fine fractions $(\geq 62$ to $<250 \mu \mathrm{m})$ were not analyzed.

Bulk magnetic susceptibility measurements were made on Cores $120-751 \mathrm{~A}-1 \mathrm{H}$ through $-10 \mathrm{H}$ on board JOIDES Resolution during the Leg 120 cruise. These measurements were conducted to delineate the location of IRD within the cores and to provide a continuous record of the IRD occurrence. Measurements were made with a Bartington magnetic susceptibility meter. Whole-round cores were passed through the sensor loop, and measurements were taken at $5-\mathrm{cm}$ intervals. The cores were exposed to a 1-Oe alternating field. Magnetic susceptibility is reported in cgs units.

The surfaces of sand grains from selected samples were examined using a JEOL-840 scanning electron microscope (SEM). Samples were coated with carbon for SEM analysis only. Surface feature categories were based on Krinsley and Donahue (1968), Margolis and Kennett (1971), and Margolis and Krinsley (1974).

\section{RESULTS}

\section{Description of Ice-rafted Debris}

The IRD from this site consists of fine to coarse sand with rare occurrences of pebble-sized dropstones. The sand is primarily composed of subangular to angular quartz, with minor amounts of feldspars, accessory minerals, and rock fragments (Appendix $\mathrm{C}$, on microfiche in back pocket). Pebble-sized IRD was observed in Cores 120-751A-1H through $-5 \mathrm{H}$. The size of each pebble and its description are summarized in Table 1. The largest pebble described is basaltic (20 $\mathrm{mm}$ ) in Sample $120-751 \mathrm{~A}-1 \mathrm{H}-1,142-144 \mathrm{~cm}$. In addition, isolated dropstones were described in the following cores: 120-751A-3H-5, $117 \mathrm{~cm}$; 120-751A-4H-2, $92 \mathrm{~cm}$; $120-751 \mathrm{~A}-$ $4 \mathrm{H}-7,80 \mathrm{~cm} ; 120-751 \mathrm{~A}-5 \mathrm{H}-1,59 \mathrm{~cm}$; and $120-751 \mathrm{~A}-5 \mathrm{H}-4,9$
Table 1. Description of pebbles detected, Site 751.

\begin{tabular}{|c|c|c|}
\hline $\begin{array}{l}\text { Core, section, } \\
\text { interval }(\mathrm{cm})\end{array}$ & Description & $\begin{array}{r}\text { Size } \\
(\mathrm{mm})\end{array}$ \\
\hline \multicolumn{3}{|l|}{$120-751 \mathrm{~A}-$} \\
\hline $1 \mathrm{H}-1,142-144$ & Basaltic & 20 \\
\hline $1 \mathrm{H}-2,10-11$ & Rock fragment & 2 \\
\hline $1 \mathrm{H}-2,79-81$ & Quartz & 4 \\
\hline $1 \mathrm{H}-2,79-81$ & Quartz & 3 \\
\hline $1 \mathrm{H}-2,79-81$ & Quartz & 2 \\
\hline $1 \mathrm{H}-3,5-7$ & Amphibole-bearing granite & 3 \\
\hline $1 \mathrm{H}-3,43-45$ & Quartz & 4 \\
\hline $1 \mathrm{H}-3,97-99$ & Granitic & 2 \\
\hline $2 \mathrm{H}-1,142-144$ & Granitic & 3 \\
\hline $2 \mathrm{H}-2,23-25$ & Rock fragment & 2 \\
\hline $2 \mathrm{H}-2,63-65$ & Quartz & 2 \\
\hline $2 \mathrm{H}-2,83-85$ & Rock fragment & 4 \\
\hline $2 \mathrm{H}-2,83-85$ & Rock fragment & 3 \\
\hline $2 \mathrm{H}-2,83-85$ & Quartz & 2 \\
\hline $2 \mathrm{H}-2,83-85$ & Quartz & 3 \\
\hline $2 \mathrm{H}-2,83-85$ & Granitic & 4 \\
\hline $2 \mathrm{H}-2,83-85$ & Granitic & 9 \\
\hline $2 \mathrm{H}-2,83-85$ & Siltstone & 8.5 \\
\hline $2 \mathrm{H}-2,103-105$ & Siltstone & 3 \\
\hline $2 \mathrm{H}-3,83-85$ & Granitic & 2 \\
\hline $3 \mathrm{H}-2,43-45$ & Rock fragment & 2 \\
\hline $5 \mathrm{H}-1,23-25$ & Metallic rock fragment & 3 \\
\hline $5 \mathrm{H}-1,23-25$ & Metallic rock fragment & 3 \\
\hline $5 \mathrm{H}-1,23-25$ & Metallic rock fragment & 3 \\
\hline $5 \mathrm{H}-1,23-25$ & Metallic rock fragment & 2 \\
\hline $5 \mathrm{H}-1,23-25$ & Metallic rock fragment & 2 \\
\hline $5 \mathrm{H}-1,103-105$ & Quartz & 2 \\
\hline $5 \mathrm{H}-1,103-105$ & Quartz & 2 \\
\hline $5 \mathrm{H}-1,103-105$ & Quartz & 2 \\
\hline $5 \mathrm{H}-1,103-105$ & Rock fragment & 2 \\
\hline $5 \mathrm{H}-2,43-45$ & Granitic & 4 \\
\hline $5 \mathrm{H}-4,5-7$ & Feldspar & 2.5 \\
\hline $5 \mathrm{H}-4,23-25$ & Quartz & 3 \\
\hline $5 \mathrm{H}-5,5-7$ & Quartz & 3 \\
\hline
\end{tabular}

$\mathrm{cm}$. Dropstones represent a variety of lithologic types, including gneiss, red sandstones, granites, and quartzite.

Sand-sized quartz grains from late Miocene, early Pliocene, late Pliocene, and Pleistocene age sediments were examined under the SEM to observe the intensity, if any, of mechanical abrasion. The SEM examination of the quartz grains revealed surface features considered diagnostic of glacially worked grains (Krinsley and Donahue, 1968; Margolis and Kennett, 1971; Margolis and Krinsley, 1974), such as extreme angularity, high relief, large- and small-scale conchoidal fractures, dish-shaped conchoidal fractures, steplike fractures, and arc-step fractures (Figs. 3-5). Throughout the entire sequence, the intensity of mechanical abrasion observed on the quartz grains appears to be the same.

Volcanic glass presumably from ash falls occurs intermittently as trace amounts. The greatest concentration of volcanic glass occurs in three intervals: (1) $6.83 \mathrm{mbsf}(=3 \mathrm{Ma})$ at a concentration of 14 grains/g; (2) between 31.25 to 32.03 mbsf $(=4.3 \mathrm{Ma})$ with concentrations ranging from 4 to 19 grains $/ \mathrm{g}$; and (3) between 37.93 and $39.43 \mathrm{mbsf}(=5.8 \mathrm{Ma}$ ) with concentrations ranging from 3 to 4 grains/g (Table 2). Sand-sized authigenic material is rare to absent at this site and is composed of pyrite, manganese micronodules, and glauconite. Authigenic material does not exceed concentrations of 2 grains/g.

\section{Ice-rafted Debris Concentrations}

Six distinct intervals of IRD occurrence separated by hiatuses (Figs. 6 and 7) were identified using the age model developed for this site (see Harwood and Maruyama, this volume, Chapter 38). Paleomagnetics and diatom-stratigraphy 


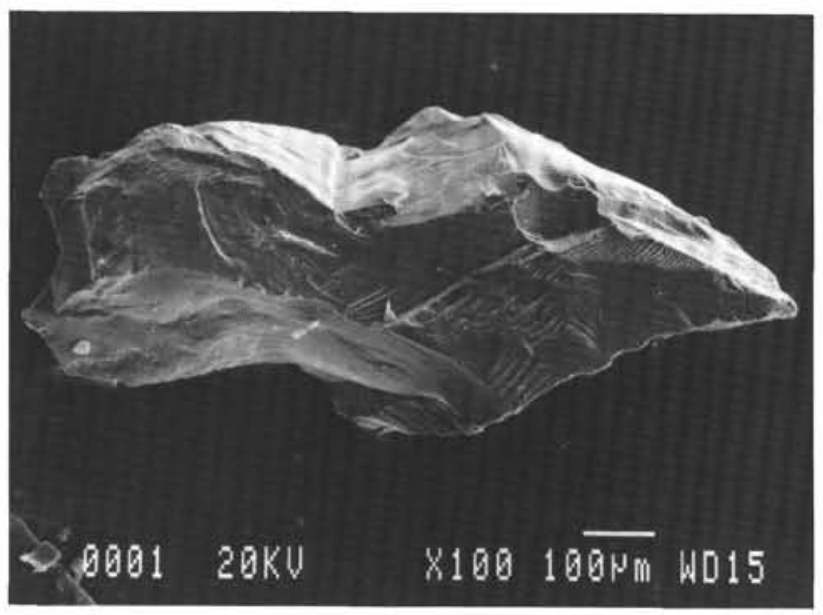

A

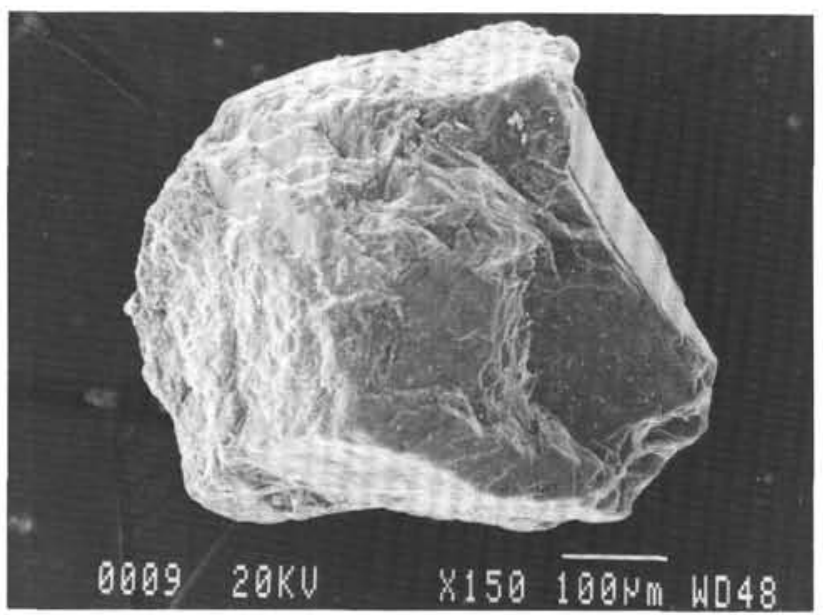

C

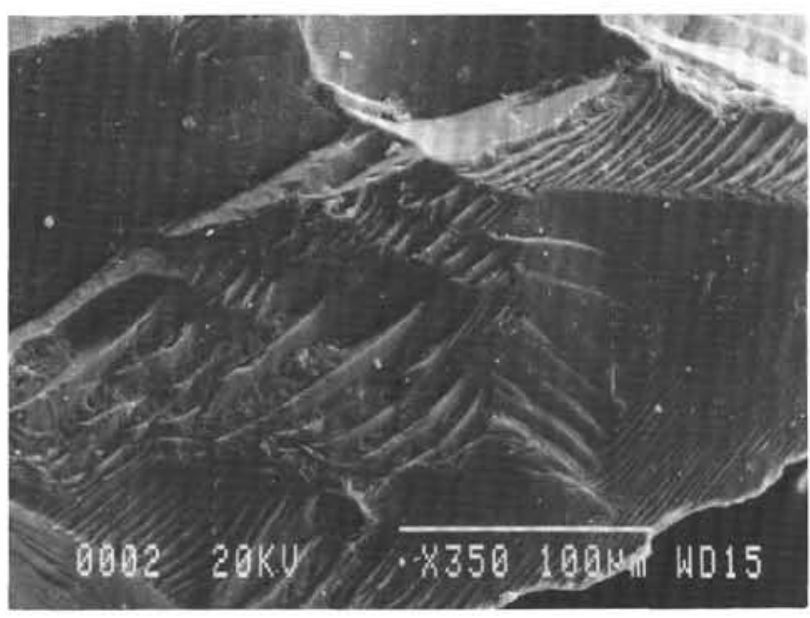

B

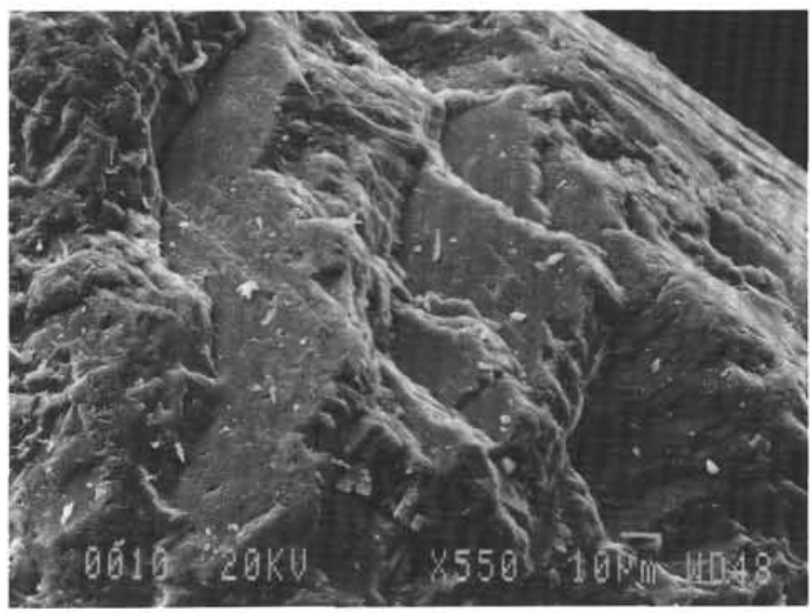

D

Figure 3. Surface texture of ice-rafted quartz sand grains. Quartz grains collected from Sample 120-751A-1 H-2, 79-81 cm (late Pliocene), at 2.29 mbsf in Interval E (Fig. 7). A JEOL-840 SEM was used to produce the micrographs. A. Angular quartz grain exhibiting blocky outline and irregular conchoidal fractures (magnification $=\times 75$ ). B. Closeup of Figure $3 \mathrm{~A}$ showing irregular conchoidal fractures and steplike fractures $($ magnification $=\times 261)$. C. Subangular quartz grain exhibiting blocky outline, steplike fractures in upper left side of grain and discontinuous overgrowth pattern (magnification = $\times 109$ ). D. Closeup of Figure $3 \mathrm{C}$ showing steplike fractures (magnification $=\times 324$ ).

were used to identify the six hiatuses within Site 751 sedimentary sequence (Table 3 ). These hiatuses may have been caused by a lack of deposition, erosion of sediments, or some combination of these factors. The hiatuses were located to within 1-2 $\mathrm{m}$ in a core (D. Harwood, pers. comm., September 1990). For purpose of discussion and calculations, the hiatuses are arbitrarily assigned to the midpoints of those intervals. Should these hiatuses be located more accurately in the future, the ages of the samples containing IRD can be recalculated from the information in Appendix D (on microfiche in back pocket). Table 3 and Appendixes $C$ and $D$ summarize the data developed from this study.

Analyses of the samples collected in upper Miocene sediments from 90.00 to 68.93 mbsf (11-9.9 Ma) did not detect IRD (Fig. 6). The first appearance of IRD in Interval A occurs at a depth of 68.73 mbsf or 9.9 Ma with an IRD concentration of 2 grains/g and apparent accumulation rate of 5.3 grains $/ \mathrm{cm}^{2} /$ k.y. (Figs. 6 and 7). Samples collected from this depth to 45.23 mbsf (9.9-8.6 Ma) were barren or contained trace amounts of IRD ( $<1$ grain/g). High bulk magnetic susceptibility measure- ments across this sequence suggest that there may be higher concentrations of IRD within this interval (Fig. 6). At the top of Interval A, the first significant concentrations of IRD were detected between 45.03 and 41.13 mbsf (8.6-8.4 Ma) (Figs. 6 and 7). A well-defined IRD peak occurs between 43.33 and 41.13 mbsf (8.53-8.41 Ma). The average IRD concentrations and accumulation rates for this peak are 11 grains/g and 22.2 grains $/ \mathrm{cm}^{2} / \mathrm{k}$.y., respectively. A hiatus that spans approximately 2.4 m.y. occurs between 41.23 and 39.43 mbsf. Figures $8 \mathrm{~A}$ and $8 \mathrm{~B}$ illustrate the abundance of IRD concentrations in Interval $A$ relative to the biogenic microfossils observed in samples containing trace levels of IRD.

The second interval of IRD concentration (Interval B) occurs in the uppermost Miocene sequence between 40.93 and 35.33 mbsf (6-5.5 Ma) (Figs. 6 and 7). This interval contains a continuous record of IRD deposition that includes three large distinct IRD peaks. Two of the IRD peaks occur near the boundaries of the two hiatuses located below and above this interval. The lowermost peak occurs at the base of Interval B between 40.03 and $39.12 \mathrm{mbsf}(5.92-5.84 \mathrm{Ma})$. This peak has 


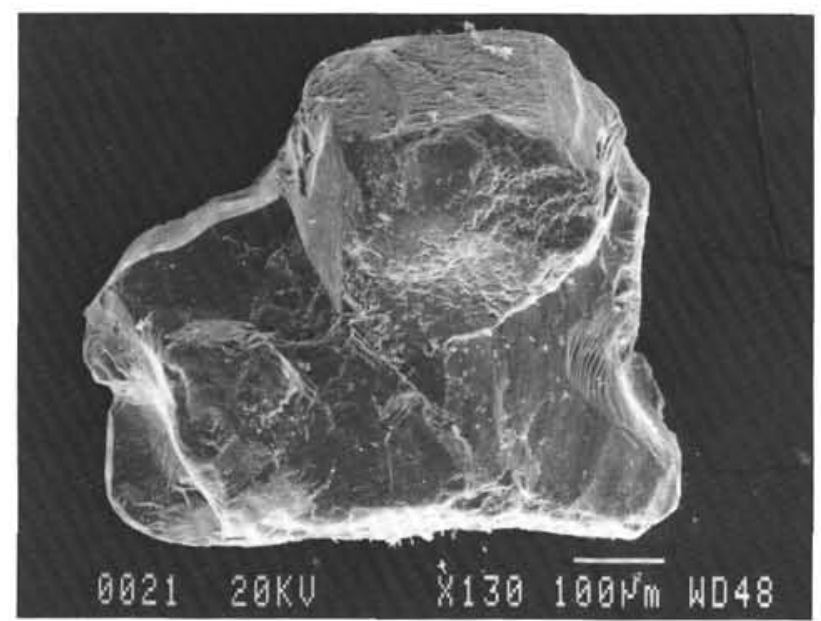

A

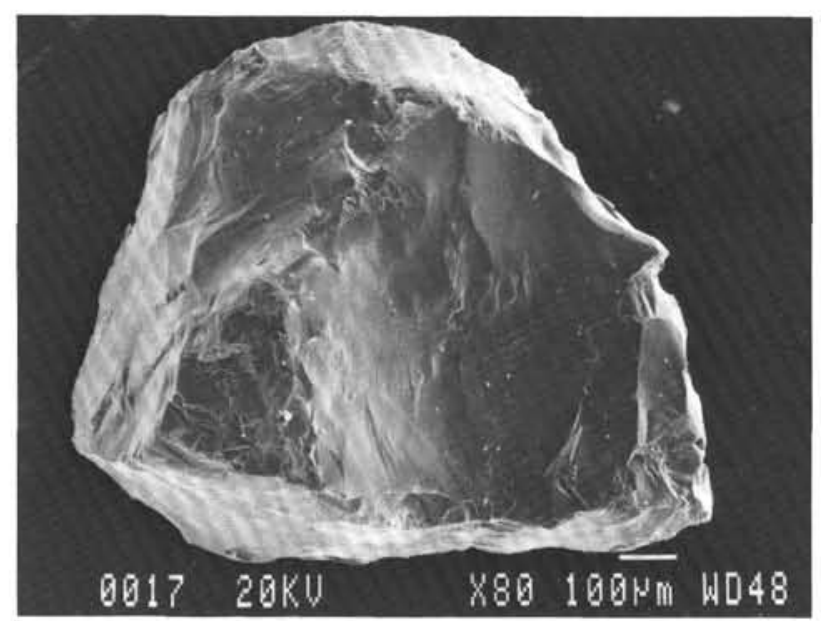

\section{c}

Figure 4. Surface texture of ice-rafted quartz sand grains. Quartz grains collected from Sample 120-751 A-2 H-1, 103-105 cm (late Pliocene), at 5.73 mbsf in Interval E (Fig. 7). A JEOL-840 SEM was used to produce the micrographs. A. Very angular quartz grain exhibiting irregular conchoidal, steplike, and arc-step fractures (magnification $=\times 98$ ). B. Closeup of Figure $4 \mathrm{~A}$ showing abundant steplike fractures (magnification $=\times 1658$ ). C. Subrounded quartz grain exhibiting large conchoidal fracture (magnification $=\times 59$ ). D. Closeup of Figure $4 \mathrm{C}$ showing conchoidal fracture surface features $(\mathrm{magnification}=\times 603$ ).

an average IRD concentration and apparent accumulation rate of 57 grains $/ \mathrm{g}$ and 144.1 grains $/ \mathrm{cm}^{2} / \mathrm{k}$.y., respectively. A prominent peak of IRD occurs in the middle of Interval B between 38.33 and 37.43 mbsf (5.77-5.70 Ma). This peak has an average IRD concentration and apparent accumulation rate of 65 grains $/ \mathrm{g}$ and 164.4 grains $/ \mathrm{cm}^{2} / \mathrm{k}$.y., respectively. The uppermost IRD peak is the largest of the three peaks in Interval B. This peak occurs between 35.93 and 35.33 mbsf (5.56-5.50 Ma) and has a maximum IRD concentration and apparent accumulation rate of 50 grains/g and 95 grains $/ \mathrm{cm}^{2} /$ k.y., respectively. A hiatus of approximately $1 \mathrm{~m} . \mathrm{y}$. occurs between 35.75 and $34.80 \mathrm{mbsf}$ and separates Intervals B and C.

The third interval of IRD concentration (Interval C) occurs in the lower Pliocene between 35.13 to 25.25 mbsf (4.5-4.1 Ma). This interval contains a continuous record of IRD deposition that includes numerous IRD events with high concentrations of IRD (Fig. 7). The largest IRD peak occurs at $34.23 \mathrm{mbsf}(4.46 \mathrm{Ma})$ with a maximum apparent accumulation rate of 1378.0 grains $/ \mathrm{cm}^{2} / \mathrm{k}$.y. The second largest IRD peak

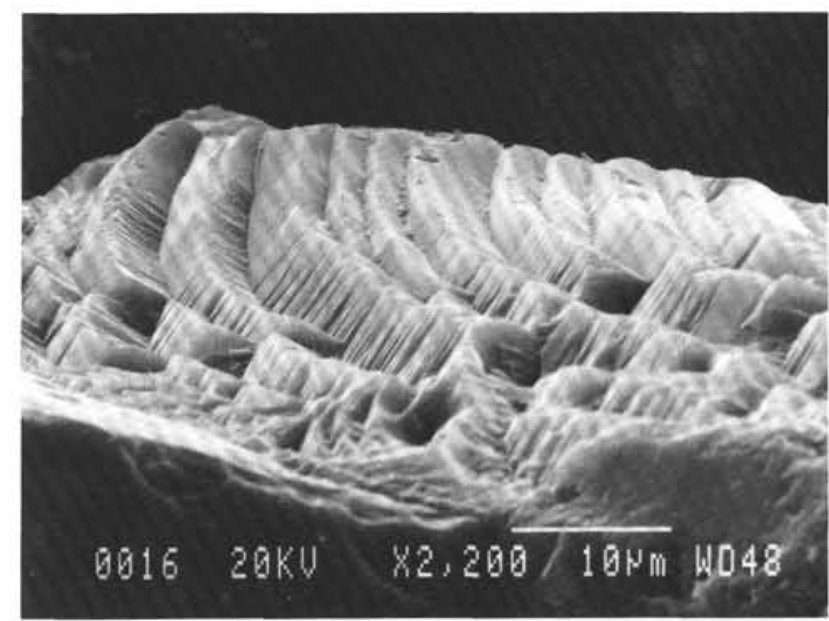

B

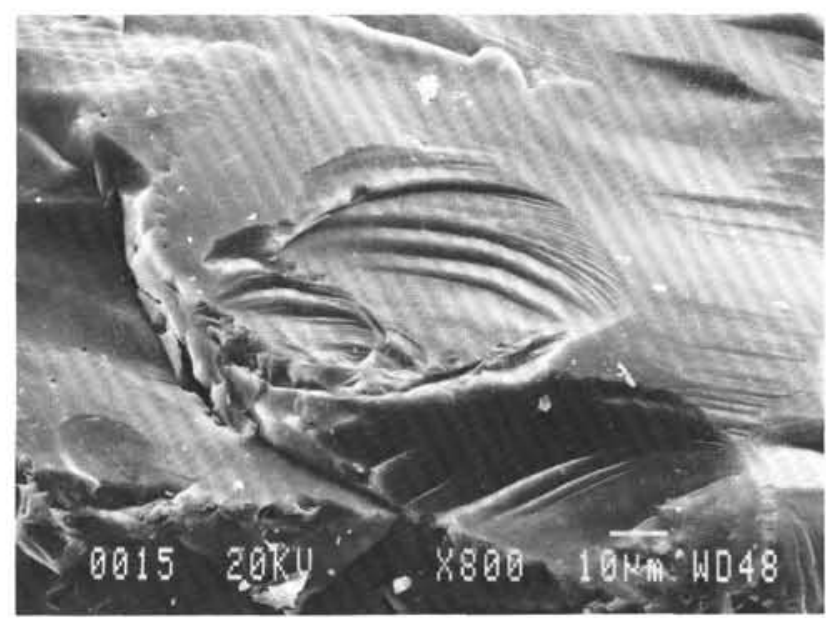

D 


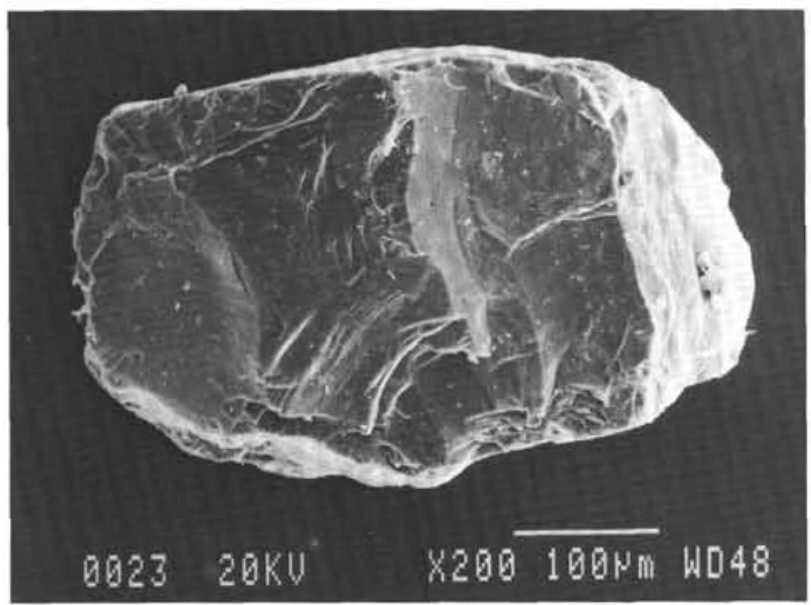

A

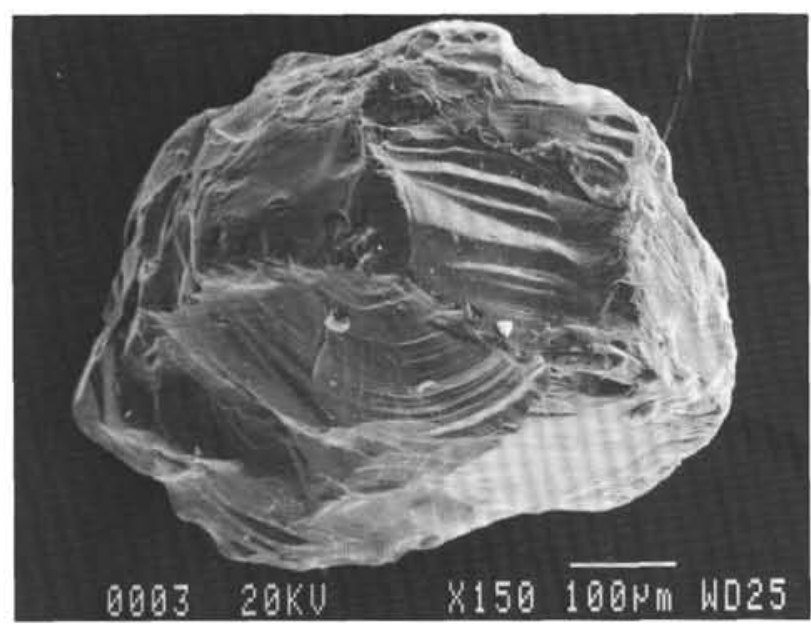

C

Figure 5. Surface texture of ice-rafted quartz sand grains. Quartz grains collected from Sample 120-751A-4H-4, 123-125 cm (Figs. 5A and 5B) (early Pliocene), and Sample 120-751A-5H-1, 103-105 cm (Figs. 5C and 5D) (early Pliocene). A JEOL-840 SEM was used to produce the micrographs. A. Angular quartz grain showing medium-relief, smooth dish-shaped conchoidal fractures, arc-shaped, steplike fractures, and blocky surface features (magnification $=\times 152$ ). B. Closeup of Figure $5 \mathrm{~A}$ showing steplike fractures (magnification $=\times 332$ ). C. Subangular quartz grain showing smooth dish-shaped conchoidal fractures (magnification $=\times 109$ ). D. Closeup of Figure $5 \mathrm{C}$ showing arc-shaped conchoidal fractures (magnification $=\times 409)$.

Table 2. Summary of volcanic glass maximum occurrence at Site $\mathbf{7 5 1}$

\begin{tabular}{|c|c|c|c|c|c|}
\hline $\begin{array}{l}\text { Core, section, } \\
\text { interval }(\mathrm{cm})\end{array}$ & $\begin{array}{l}\text { Depth } \\
\text { (mbsf) }\end{array}$ & $\begin{array}{c}\text { Dry } \\
\text { weight } \\
\text { bulk } \\
\text { sample }\end{array}$ & $\begin{array}{c}\text { Number of } \\
\text { volcanic } \\
\text { glass } \\
\text { grains }\end{array}$ & $\begin{array}{l}\text { Volcanic } \\
\text { glass } \\
\text { (grains } / g \text { ) }\end{array}$ & $\underset{\text { (grains/g) }}{\operatorname{IRD}}$ \\
\hline \multicolumn{6}{|l|}{$120-751 \mathrm{~A}-$} \\
\hline $2 \mathrm{H}-2,63-65$ & 6.83 & 3.095 & 42 & 14 & 46 \\
\hline $4 \mathrm{H}-6,5-7$ & 31.25 & 3.675 & 19 & 5 & 26 \\
\hline $4 \mathrm{H}-6,23-25$ & 31.43 & 3.387 & 12 & 4 & 26 \\
\hline $4 H-6,63-65$ & 31.83 & 2.160 & 32 & 15 & 19 \\
\hline $4 \mathrm{H}-6,83-85$ & 32.03 & 3.133 & 59 & 19 & 6 \\
\hline $5 \mathrm{H}-4,23-25$ & 37.93 & 3.464 & 13 & 4 & 79 \\
\hline SH-5, $5-7$ & 39.25 & 5.970 & 16 & 3 & 78 \\
\hline $5 \mathrm{H}-5,23-25$ & 39.43 & 4.479 & 19 & 4 & 60 \\
\hline
\end{tabular}

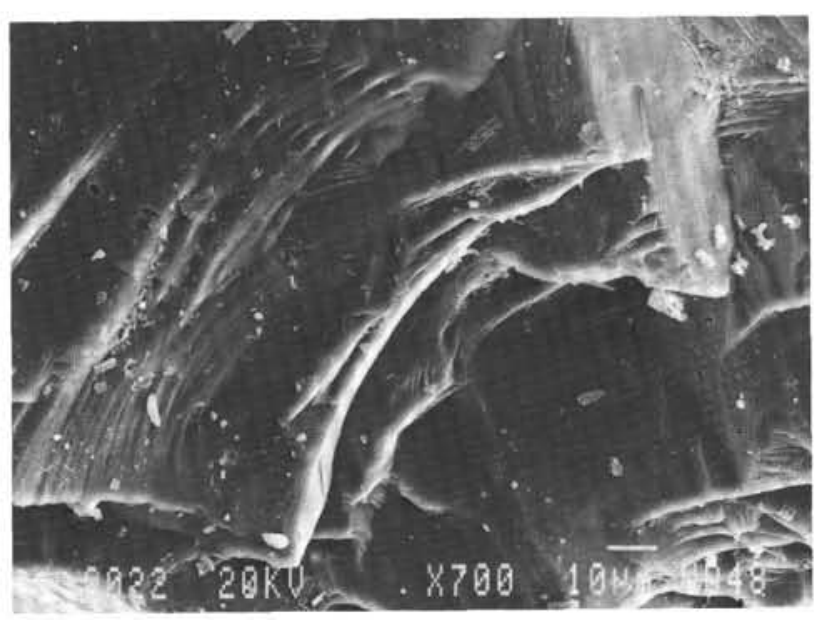

$\mathbf{B}$

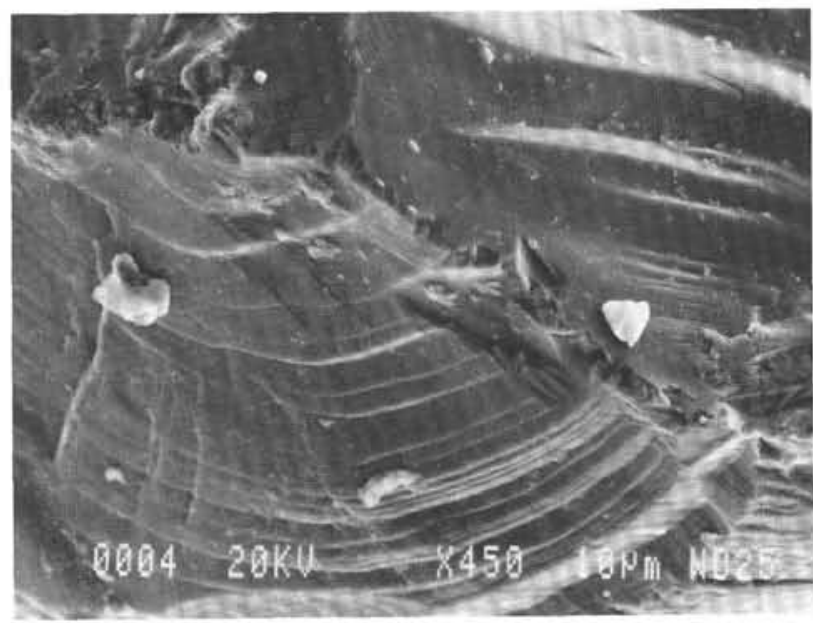

D 


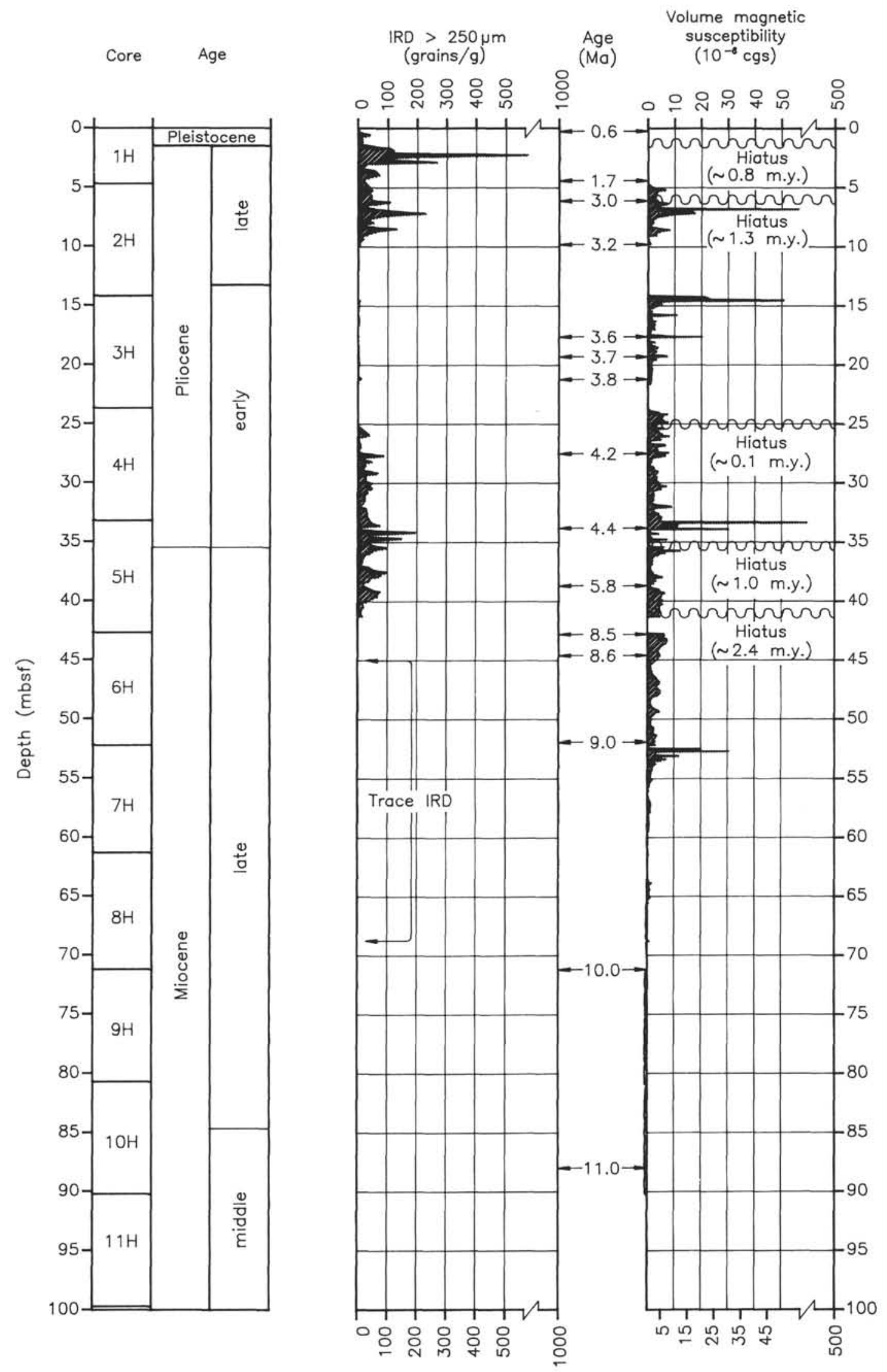

Figure 6. Variation of IRD concentration (grains/g) compared with bulk magnetic susceptibility (cgs) at Site 751. Magnetic susceptibility signal intensity corresponds with IRD grains/g increases. IRD $=$ ice-rafted debris. 


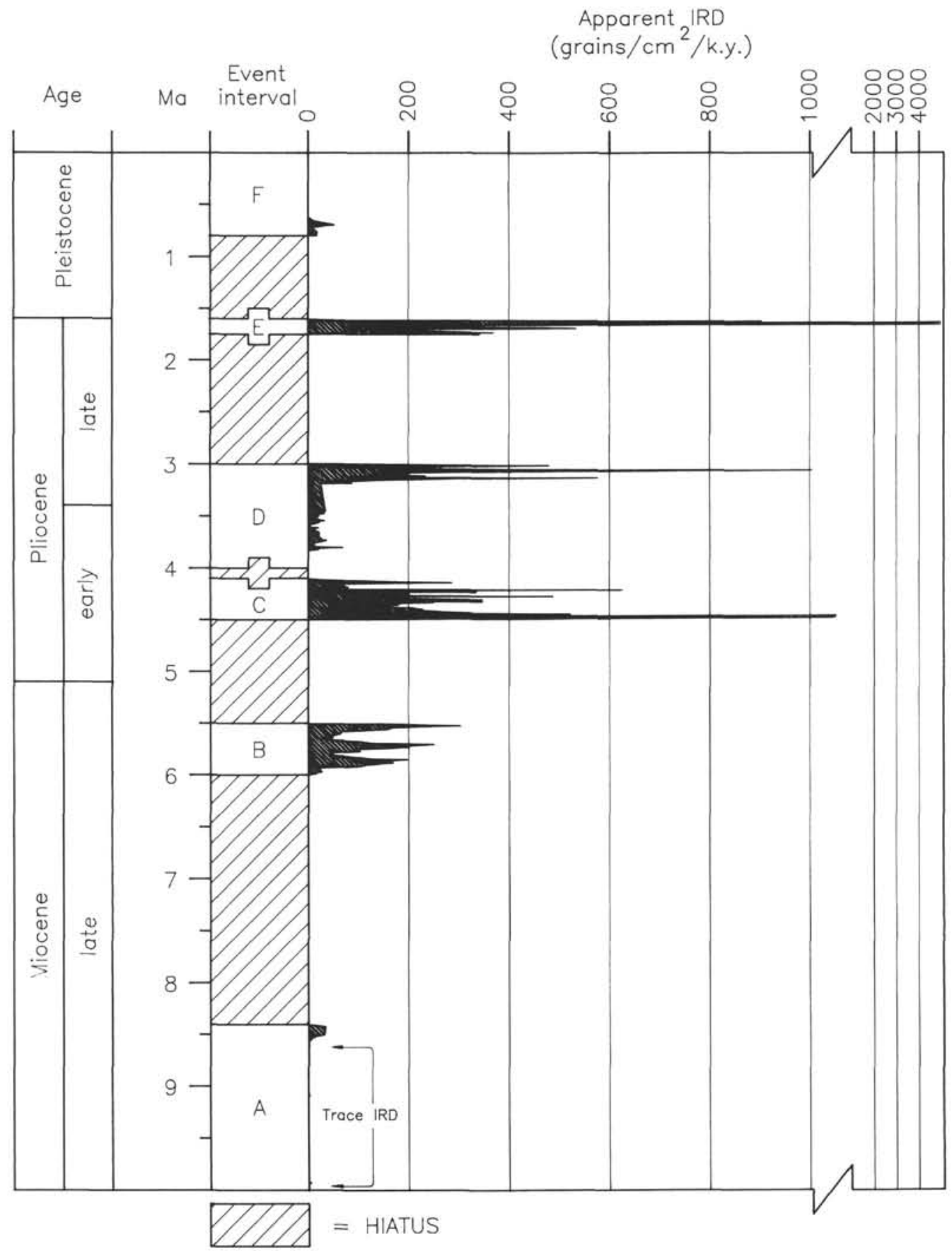

Figure 7. Variation of apparent accumulation rates for IRD (grains $/ \mathrm{cm}^{2} / \mathrm{k} . \mathrm{y}$.) at Site 751 . Intervals delineate events of IRD deposition. IRD = ice-rafted debris.

In addition, this interval contains a continuous record of high IRD apparent accumulation rates. The average IRD concentration and apparent accumulation rates for Interval $\mathrm{E}$ are 110 grains $/ g$ and 812 grains $/ \mathrm{cm}^{2} / \mathrm{k}$.y., respectively. The largest of the five peaks was detected at $2.29 \mathrm{mbsf}(1.63 \mathrm{Ma})$, with concentrations and apparent accumulation rates of 705 grains $/ \mathrm{g}$ and 5225.2 grains $/ \mathrm{cm}^{2} / \mathrm{k}$.y., respectively (Figs. 6 and 7). Other significant peaks occur at $1.67,1.65$, and $1.62 \mathrm{Ma}$. A hiatus of approximately $0.8 \mathrm{Ma}$ occurs between 1.45 and 1.05 mbsf and separates Intervals $\mathrm{E}$ and $\mathrm{F}$.

The sixth interval (Interval F) lies between 1.03 and 0.23 mbsf $(=0.8$ and $=0.5 \mathrm{Ma})$ in the Pleistocene, with maximum
IRD concentrations and accumulation rates of 42 grains/g and 53.3 grains $/ \mathrm{cm}^{2} /$ k.y., respectively. Figures $9 \mathrm{D}, 9 \mathrm{E}$, and $9 \mathrm{~F}$ illustrate the abundance of IRD concentrations relative to the biogenic microfossils observed in samples collected from Intervals $\mathrm{E}$ and $\mathrm{F}$.

\section{DISCUSSION}

The high-resolution sampling of Site 751 provides an excellent record of variations in the amount of IRD delivered to the Kerguelen Plateau from 9.9 Ma to the present. This discussion of IRD events compares Site 751 results with the IRD studies on Deep Sea Drilling Project (DSDP) Sites 511, 
Table 3. Summary of IRD event intervals: depth interval, age interval, and interval sedimentation rate.

\begin{tabular}{cccc}
\hline $\begin{array}{c}\text { Event } \\
\text { interval }\end{array}$ & $\begin{array}{c}\text { Depth } \\
(\mathrm{mbsf})\end{array}$ & $\begin{array}{c}\text { Age } \\
\text { interval } \\
(\mathrm{Ma})\end{array}$ & $\begin{array}{c}\text { Sedimentation } \\
\text { rate } \\
(\mathrm{m} / \mathrm{m} . \mathrm{y} .)\end{array}$ \\
\hline Hiatus & 0.05 & $0.0-0.58$ & $\mathrm{NA}$ \\
$\mathrm{F}$ & $0.05-1.25$ & $0.58-0.8$ & 5.45 \\
Hiatus & 1.25 & $0.8-1.6$ & $\mathrm{NA}$ \\
E & $1.25-6.03$ & $1.6-1.75$ & 31.87 \\
Hiatus & 6.03 & $1.75-3.0$ & $\mathrm{NA}$ \\
D & $6.03-24.98$ & $3.0-4.0$ & 18.95 \\
Hiatus & 24.98 & $4.0-4.1$ & $\mathrm{NA}$ \\
C & $24.98-35.28$ & $4.1-4.5$ & 25.75 \\
Hiatus & 35.28 & $4.5-5.5$ & $\mathrm{NA}$ \\
B & $35.28-41.00$ & $5.5-6.0$ & 11.44 \\
Hiatus & 41.00 & $6.0-8.4$ & $\mathrm{NA}$ \\
A & $41.00-90.00$ & $8.4-11.1$ & 18.15 \\
\hline
\end{tabular}

512, 513, and 514 during Leg 71 (Bornhold, 1983) and with Islas Orcadas piston cores (1176-66 and 0775-5) analyzed by Anderson (1985). Comments are provided on the significance of this comparison in postulating paleoclimatic changes during the Neogene. Leg 71 sites are located in the Southern Atlantic Ocean in the vicinity of the Falkland Plateau and the Maurice Ewing Bank (Fig. 10). Islas Orcadas piston Core 1176-66 was collected in the Weddell Abyssal Plain ( $\left.57^{\circ} 55.3^{\prime} \mathrm{S} ; 8^{\circ} 59.0^{\prime} \mathrm{E}\right)$. Islas Orcadas piston Core 0775-05 was collected in the northern sector of the Georgia Basin $\left(48^{\circ} 51.2^{\prime} \mathrm{S} ; 36^{\circ} 33.3^{\prime} \mathrm{W}\right)$ (Fig. 10).

\section{Late Miocene}

The oldest IRD found at Site 751 was approximately $9.9 \mathrm{Ma}$ (Interval A) (Fig. 7). This event consisted of very low abundance of quartz sands with apparent accumulation rates not exceeding 5.3 grains $/ \mathrm{cm}^{2} / \mathrm{k}$.y. A large portion of Interval A (Fig. 7) represents a period of negligible levels of ice-rafting from 9.9 to $8.6 \mathrm{Ma}$. This interval is primarily barren of clastic material; however, some samples analyzed contained $<1$ grain/g of IRD. The first significant concentration of IRD occurred $=8.5 \mathrm{Ma}$ (Fig. 7).

Directly above Interval A, a major hiatus of 2.4 m.y. occurred between 8.4 and 6 Ma. Bornhold (1983) notes a major erosional phase occurred on the Maurice Ewing Bank between 7.2 and $6.3 \mathrm{Ma}$. We propose that the hiatus detected at Site 751 between 8.4 and $6 \mathrm{Ma}$ is related to the erosional event on Maurice Ewing Bank. As suggested by Bornhold (1983), the erosional event on Maurice Ewing Bank can be attributed to the expansion of the West Antarctica Ice Sheet (WAIS) and to the increase in the Antarctic Circumpolar Current circulation (ACC). Also, Wise et al. (1985 and references therein) postulated that the WAIS was fairly unstable during the late Miocene, thus affecting the production of Antarctic Bottom Water (AABW) and the velocity of the ACC. The change in ACC flow velocities during the formation of the WAIS may be indirectly related to the erosional event that occurred at Site 751 during the late Miocene.

The first major IRD events encountered at Site 751 are in the uppermost Miocene (Interval B). This interval of increased IRD contains three distinct ice-rafting events that are similar in duration and magnitude. The three IRD events appear to be cyclic, in that they are separated by periods of greatly reduced IRD deposition. This IRD activity occurred over a period of 0.5 m.y. from 6 to $5.5 \mathrm{Ma}$ (Fig. 7), reaching peaks at $5.85,5.7$, and $5.52 \mathrm{Ma}$. In contrast, Sites 513 and 514 on Leg 71 experienced reduced ice-rafting activity between 6.5 and 5.5 Ma.
The most significant ice-rafting event within Interval B occurred between 5.56 and $5.5 \mathrm{Ma}$. This ice-rafting event appears to correspond with an interval of increased IRD concentration detected at Site 513, which occurred between 5.5 and 5.0 Ma and reached a peak at 5.46 Ma. Bornhold (1983) suggested that the event encountered in Site 513 at 5.46 $\mathrm{Ma}$ took place within a period of general climatic cooling and glacial expansion that began about $6.0 \mathrm{Ma}$ (Loutit and Kennett, 1979) and lasted until about 5.2 Ma.

\section{Early Pliocene}

A hiatus of $1 \mathrm{~m} . \mathrm{y}$. separates ice-rafting event Intervals B and $C$ (Figure 7). Directly after the hiatus, continuous IRD deposition occurred from 4.5 to 4.1 Ma. Maximum IRD peaks in Interval $\mathrm{C}$ occurs at $4.48,4.46$, and $4.2 \mathrm{Ma}$. The timing of these IRD events on the Kerguelen Plateau corresponds with IRD fluxes observed on the Falkland Plateau (Bornhold, 1983) and in the Weddell Abyssal Plain and Georgia Basin (Anderson, 1985). Figure 11 compares the occurrence of IRD on the Kerguelen Plateau with those of the Weddell Abyssal Plain and Georgia Basin. Site 751 is located at latitude $58^{\circ} \mathrm{S}$ in 1634 $\mathrm{m}$ of water, Islas Orcadas Core 1176-66 at latitude $58^{\circ} \mathrm{S}$ in $4513 \mathrm{~m}$ of water, and Islas Orcadas Core 0775-5 at latitude $49^{\circ} \mathrm{S}$ in $4895 \mathrm{~m}$ of water. They are all located south of the present-day Polar Front. Assuming the age model used by Anderson (1985) was similar to that used for Site 751, the largest IRD peaks observed in each core occur within the same general time frame: Site 751 at $4.48 \mathrm{Ma}$ and Islas Orcadas Cores $0775-5$ and $1176-66$ at $4.50 \mathrm{Ma}$. The third largest IRD flux observed in Site 751 correlates to an IRD peak in Islas Orcadas Core 0775-5 at 4.2 Ma. The synchronous timing of these peaks ( 4.5 and $4.2 \mathrm{Ma})$, coupled with the vast distances between the Kerguelen Plateau and the Weddell Abyssal Plain and Georgia Basin $(>11,000 \mathrm{~km})$, suggest that a major global climatic event of far-reaching effects occurred during early Pliocene time. This global climatic event may have been caused by a major reduction of ice volume on Antarctica, supported by the discussion below.

Shallow marine deposits that occur above the present-day sea level on Antarctica's Marine Plain in the Vestford Hills have been dated as 4.5-3.5 Ma (early Pliocene age) using diatom biostratigraphy (Harwood, 1986). Based on Harwood's age dates, Pickard et al. (1988) suggested that the paleoenvironmental conditions indicate that the early Pliocene was a strong interglacial period. Other authors support an interpretation that deglaciation and a marine invasion of the Antarctic craton occurred during early Pliocene times (Harwood, 1983, 1985; Webb et al., 1984) as well as a partial deglaciation of the WAIS (Ciesielski et al., 1982). Several investigators have suggested that these warm climatic conditions existed in Antarctica between 4.4 and 4.0 Ma (Ciesielski and Weaver, 1974; Weaver, 1976). Bornhold (1983) reported IRD at Site 513 for the period between 4.8 and $4.3 \mathrm{Ma}$. He suggested that ice-rafting during this period may be attributed to the deterioration of the WAIS. Based on the above discussion and the occurrence of IRD on the Kerguelen Plateau linked to this time period, it is plausible that the East Antarctic Ice Sheet (EAIS) experienced deglaciation at that time and, as a result, released large volumes of sediment-laden ice into the Southern Ocean.

A period of reduced and continuous ice-rafting (Interval D) occurred at Site 751 from about 4 to $3.17 \mathrm{Ma}$. From 3.16 to $3.0 \mathrm{Ma}$, a major IRD event occurred that supplied abundant IRD to the Kerguelen Plateau (Fig. 7). At Sites 513 and 514, IRD accumulation rates were highly variable, with a major IRD event occurring between 4.1 and $3.9 \mathrm{Ma}$. The IRD peak detected at $4.1 \mathrm{Ma}$ at Sites 513 and 514 was not 


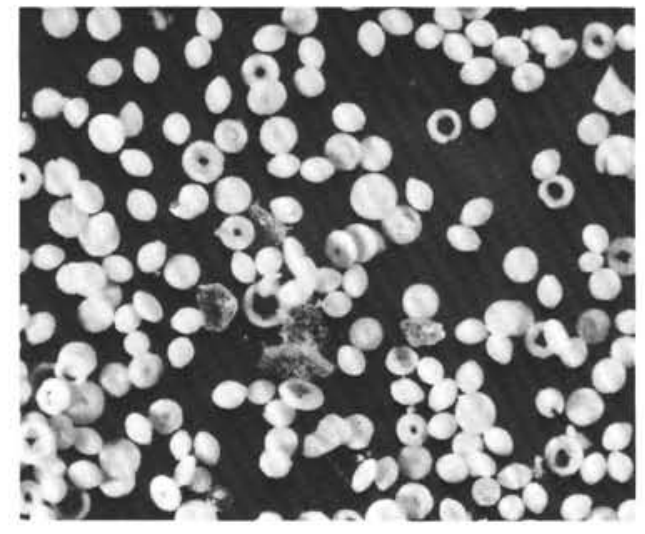

A

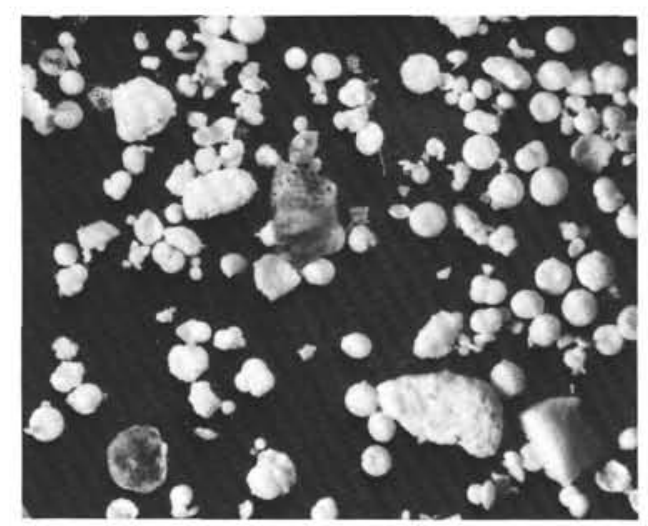

C

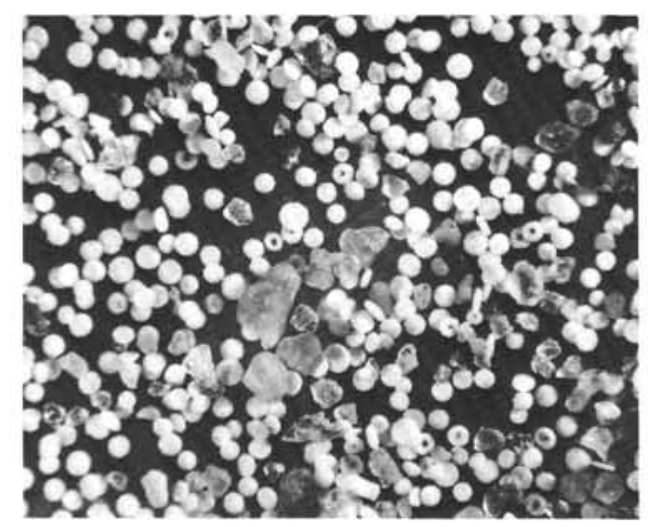

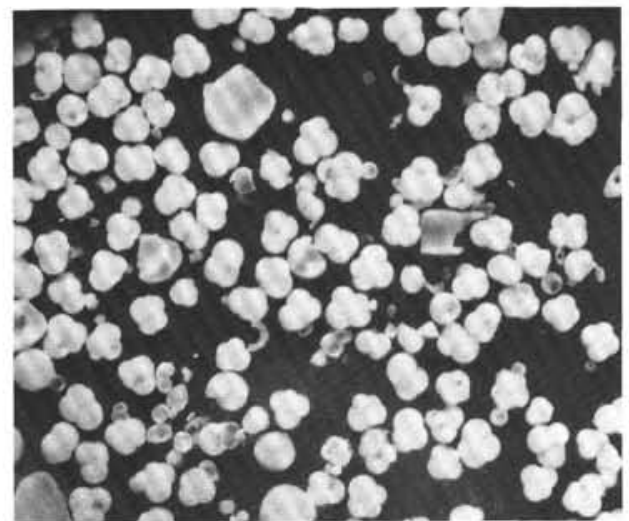

B

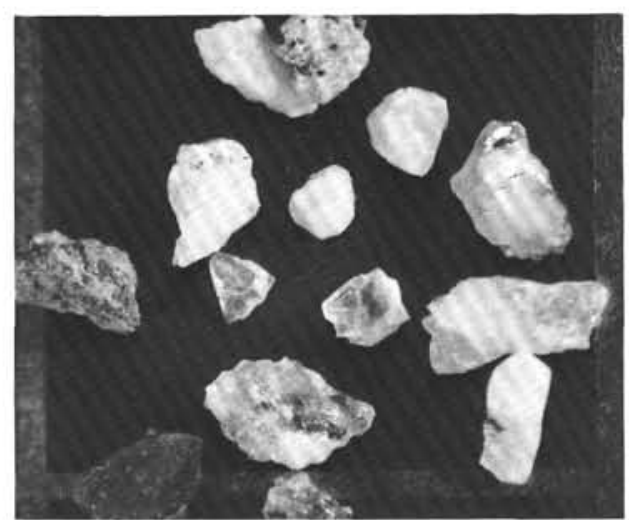

D

E

Figure 8 . This figure illustrates late Miocene and early Pliocene IRD abundance relative to microfossil occurrence viewed through a binocular microscope. A. Sample 120-751A-6H-4, 63-65 cm (late Miocene), at 47.83 mbsf in Interval A (Fig. 7); $\geq 250$ - $\mu \mathrm{m}$-size fraction showing trace amounts of ice-rafted quartz grains and abundant carbonate microfossils. The apparent accumulation rate of the IRD for this sample is 1.0 grains $/ \mathrm{cm}^{2} / \mathrm{k}$.y. B. Sample 120-751A-7H-1, 123-125 cm (late Miocene), at $53.43 \mathrm{mbsf}$ in Interval A (Fig. 7); $\geq 250-\mu \mathrm{m}$ size fraction showing trace ice-rafted quartz grains and abundant carbonate microfossils. The apparent accumulation rate of the IRD for this sample is 2.8 grains $/ \mathrm{cm}^{2} / \mathrm{k}$.y. C. Sample $120-751 \mathrm{~A}-4 \mathrm{H}-4$, $123-125 \mathrm{~cm}$ (early Pliocene), at $29.43 \mathrm{mbsf}$ in Interval C (Fig. 7); $\geq 250-\mu \mathrm{m}$-size fraction showing ice-rafted quartz grains and abundant siliceous microfossils. The apparent accumulation rate of the IRD for this sample is 90.5 grains $/ \mathrm{cm}^{2} / \mathrm{k}$.y. D. Sample $120-751 \mathrm{~A}-5 \mathrm{H}-1,103-105 \mathrm{~cm}$ (early Pliocene), at 34.23 mbsf between Interval C (Fig. 7); >1-mm-size fraction showing pebble-sized, ice-rafted quartz and rock fragments. The apparent accumulation rate of the IRD for this sample is 1378.0 grains $/ \mathrm{cm}^{2} / \mathrm{k} . y$. E. Sample $120-751 \mathrm{~A}-5 \mathrm{H}-1$, $103-105 \mathrm{~cm}$ (early Pliocene) at 34.23 mbsf between Interval C (Fig. 7); $\geq 250$ - $\mu \mathrm{m}$-size fraction showing abundant ice-rafted quartz grains and abundant siliceous microfossils. The apparent accumulation rate of the IRD for this sample is 1378.0 grains $/ \mathrm{cm}^{2} / \mathrm{k} . \mathrm{y}$. 


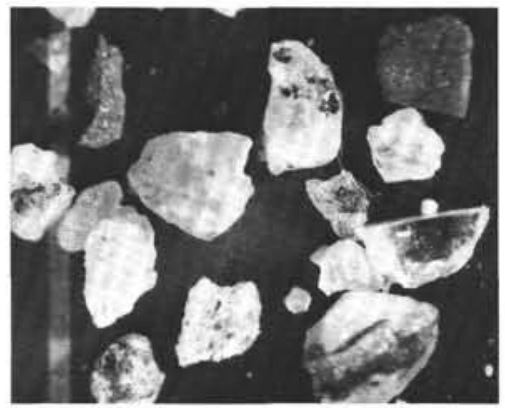

A

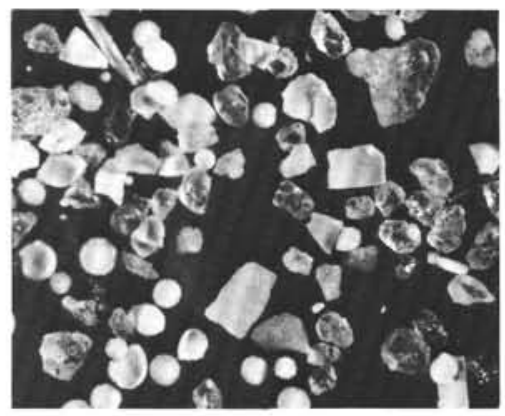

C

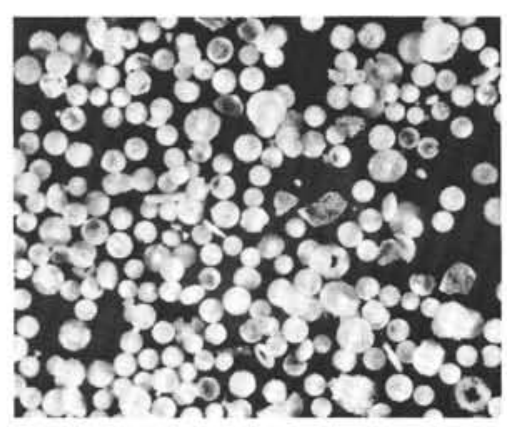

$\mathbf{E}$

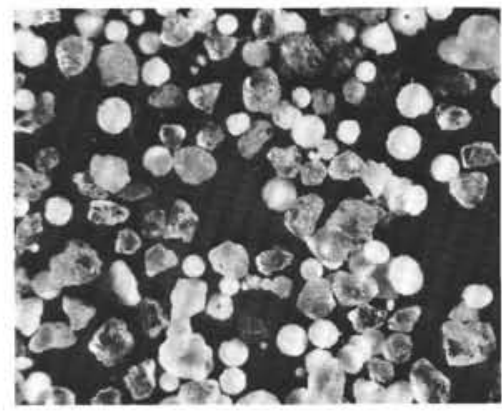

B

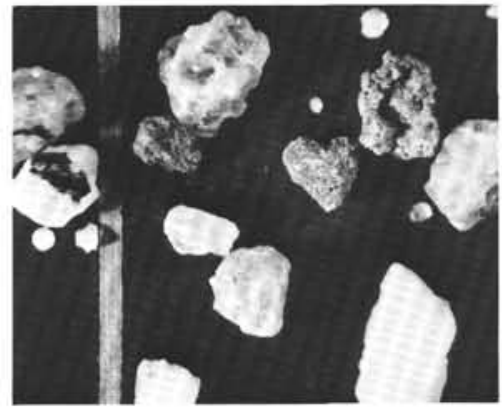

D

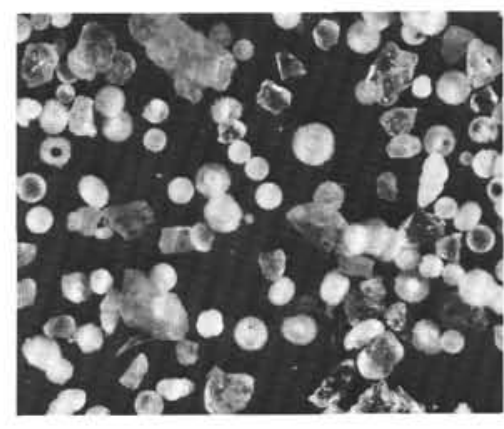

$\mathbf{F}$

Figure 9. This figure is an example of late Pliocene and Pleistocene IRD debris abundance relative to microfossil occurrence viewed through a binocular microscope. A. Sample $120-751 \mathrm{~A}-2 \mathrm{H}-2,83-85 \mathrm{~cm}$ (late Pliocene), at $7.03 \mathrm{mbsf}$ in Interval D (Fig. 7). >1-mm size fraction showing pebble-sized, ice-rafted quartz, feldspar, and rock. The apparent accumulation rate of the IRD for this sample is 537.7 grains $/ \mathrm{cm}^{2} /$ k.y. B. Sample 120-751A-2H-2, 103-105 cm (late Pliocene), at $7.23 \mathrm{mbsf}$ in Interval D (Fig. 7); $\geq 250-\mu \mathrm{m}$-size fraction showing abundant ice-rafted quartz grains and few siliceous microfossils. The apparent accumulation rate of the IRD for this sample is 1004.8 grains $/ \mathrm{cm}^{2} / \mathrm{k}$.y. C. Sample $120-751 \mathrm{~A}-2 \mathrm{H}-3,83-85 \mathrm{~cm}$ (late Pliocene), at 8.53 mbsf in Interval D (Fig. 7); $\geq 250-\mu \mathrm{m}$-size fraction showing abundant ice-rafted quartz grains and few siliceous microfossils. The apparent accumulation rate of the IRD for this sample is 577.3 grains $/ \mathrm{cm}^{2} / \mathrm{k}$.y. D. Sample $120-751 \mathrm{~A}-1 \mathrm{H}-2,79-81 \mathrm{~cm}$ (late Pliocene), at 2.29 mbsf in Interval E (Fig. 7); >1-mm-size fraction showing pebble-sized, ice-rafted quartz, feldspar, and rock. The apparent accumulation rate of the IRD for this sample is 5225.2 grains $/ \mathrm{cm}^{2} /$ k.y. E. Sample $120-751 \mathrm{~A}-1 \mathrm{H}-2,79-81$ $\mathrm{cm}$ (late Pliocene), at $2.29 \mathrm{mbsf}$ in Interval F (Fig. 7); $\geq 250-\mu \mathrm{m}$-size fraction showing some ice-rafted quartz grains and abundant siliceous microfossils. The apparent accumulation rate of the ice-rafted debris for this sample is 5225.2 grains $/ \mathrm{cm} 2 / \mathrm{k} . \mathrm{y}$. F. Sample 120-751A-1H-1, 63-65 cm (Pleistocene), at $0.63 \mathrm{mbsf}$ in Interval F (Fig. 7); $\geq 250$ - $\mu \mathrm{m}$-size fraction showing few ice-rafted quartz grains and abundant siliceous microfossils. The apparent accumulation rate of the IRD for this sample is 53.3 grains $/ \mathrm{cm}^{2} / \mathrm{k}$.y. 


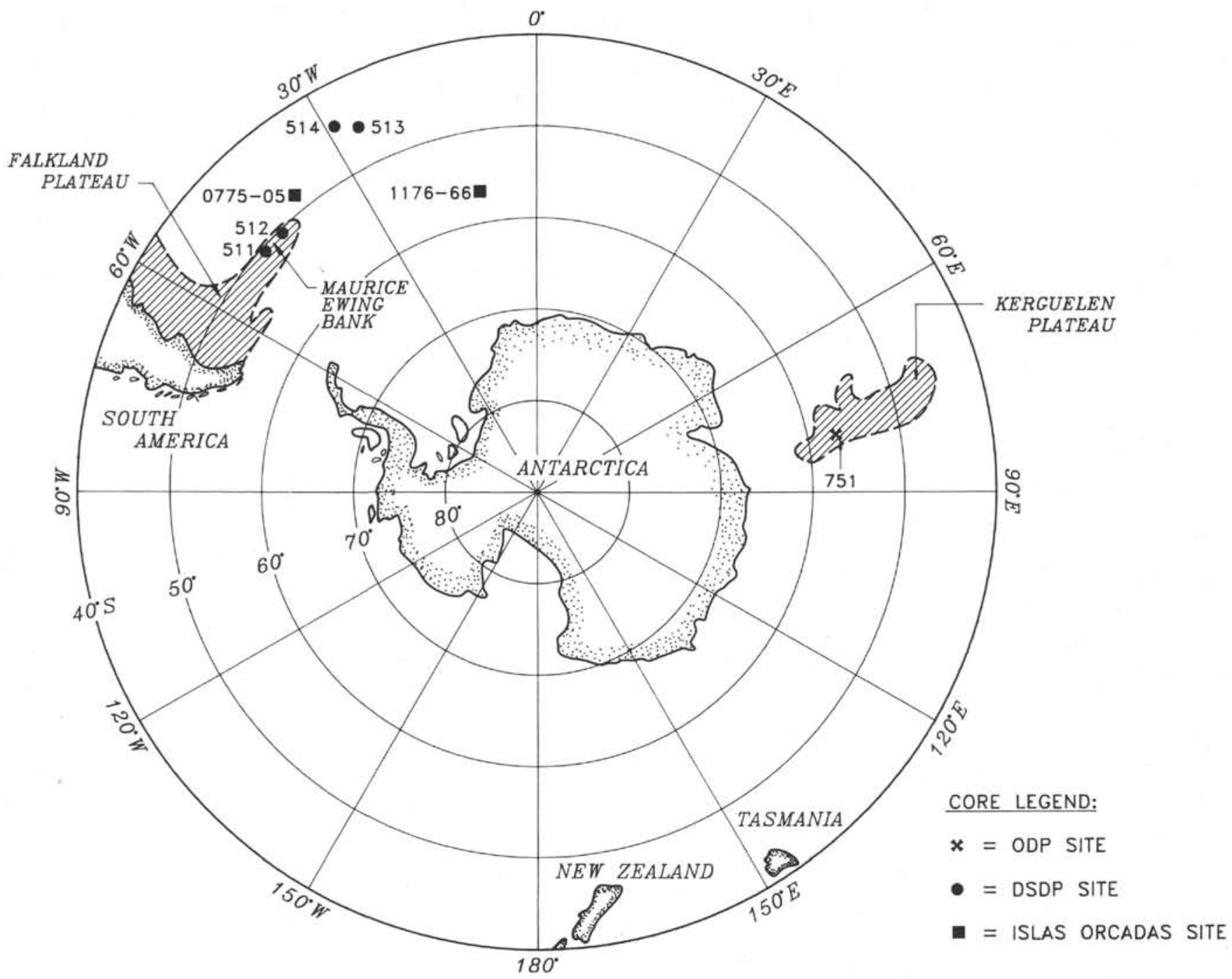

Figure 10. Map showing the location of Leg 71 Sites 511, 512, 513, and 514 as well as Islas Orcadas sites for Cores 1176-66 and 0775-05.

detected at Site 751 . A short-duration hiatus $(0.1$ m.y.) probably destroyed any IRD record that may have been deposited at Site 751 during this time period. Bornhold (1983) suggested that the IRD detected at Sites 513 and 514 reflects a major cooling trend that began about $4.2 \mathrm{Ma}$ and continued until about $3 \mathrm{Ma}$. In addition, Ciesielski and Weaver (1974) reported a major cooling trend in the Southern Ocean region between 3.95 and $3.7 \mathrm{Ma}$. According to Ciesielski and Wise (1977), temperatures fell steadily after the early Pliocene warm interval until 3.7 to $3.5 \mathrm{Ma}$ and then stayed low throughout much of the Pliocene.

Weaver (1973) and Ciesielski and Weaver (1974) suggested that Antarctic conditions were more severe during the period between 3.8 and $3.45 \mathrm{Ma}$ than at present. Why were significant levels of IRD being delivered to the Falkland Plateau region and not to the Kerguelen Plateau during this time when global temperatures were reported as cooling? Low levels of IRD at Site 751 may be attributed to the isolated geographic location of the Kerguelen Plateau as well as a change in direction and/or velocity of the ACC. A change in current direction may have affected the iceberg-tracking paths, delivering sedimentladen icebergs to areas north or south of Site 751. A decrease in ACC velocity may have enhanced the melting rate of the icebergs, allowing the bergs ample time to melt before reach- ing Site 751. In addition, the icebergs could have been confined close to Antarctica's shoreline as a result of increased sea-ice and shelf-ice formation.

\section{Late Pliocene}

In the uppermost Pliocene, a hiatus of $1.3 \mathrm{~m} . \mathrm{y}$. is dated in this section between 3 and 1.75 Ma. Osborn et al. (1983) reported a hiatus of similar duration and timing in the South Indian Basin sediments between 3.4 and $2.0 \mathrm{Ma}$ and suggested that the deep-sea sediments were eroded by the shallow ACC or Circumpolar Deep Water (CDW). Continuous and elevated levels of IRD concentrations occurred from 1.75 to $1.6 \mathrm{Ma}$ (Interval E), reaching a maximum peak at $1.63 \mathrm{Ma}$ (Fig. 7). Based on stable isotopic records, Shackleton and Kennett (1975) suggested that a cooling trend occurred in the Southern Hemisphere during this time period. However, the Blank and Margolis (1975, fig. 6) study of Southeast Indian Ocean cores suggested that a fairly warm climatic trend occurred from the Gauss through early Matuyama (3.4-0.8 Ma).

\section{Pleistocene}

A hiatus of 1.0 m.y. between Intervals E and F (Fig. 7) occurred between 1.6 and $0.8 \mathrm{Ma}$. Osborn et al. (1983) reported the occurrence of two hiatuses between 2.1 and 1.2 

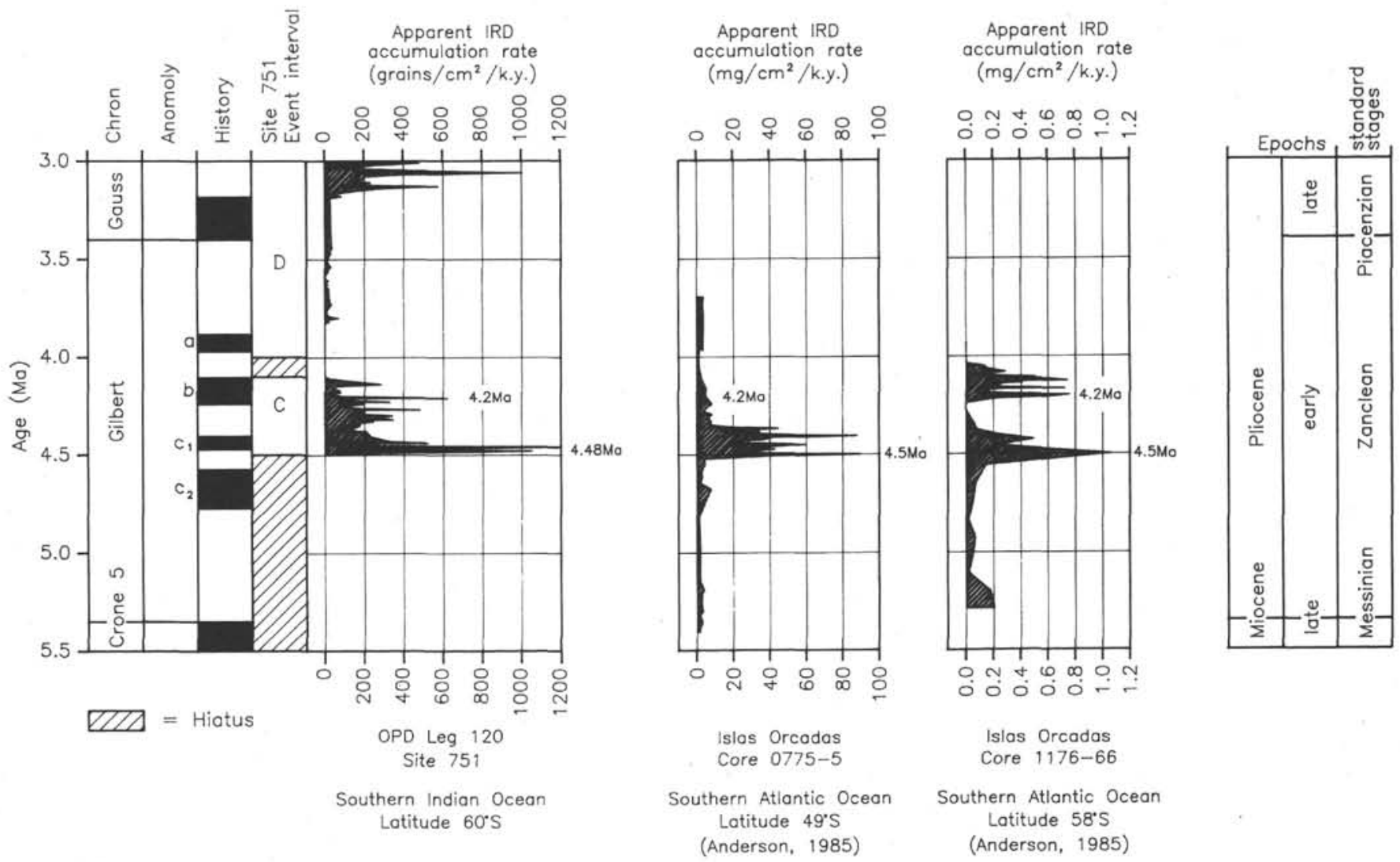

Figure 11. Global comparison of IRD occurrence and concentrations between Site 751 located in the Southern Indian Ocean (Fig. 1) and Islas Orcadas Cores 1176-66 and 0775-05 located in the Southern Atlantic Ocean (Fig. 10).

$\mathrm{Ma}$ in cores from the South Indian Basin southeast of the Kerguelen Plateau.

The hiatuses between 3 and $1.75 \mathrm{Ma}$ and between 1.6 and 0.8 $\mathrm{Ma}$ at Site 751 represent a total of 2 m.y. within latest Pliocene and Pleistocene. As a result most of the upper Pliocene and Pleistocene IRD record was not recovered at Site 751 .

Low rates of IRD accumulation characterize Interval $\mathrm{F}$ from 0.8 to $0.6 \mathrm{Ma}$. However, during this time period, very high IRD accumulation rates were reported at Site 514 (Bornhold, 1983), Maurice Ewing Bank (Ciesielski et al., 1982) and southeast Indian Ocean (Keany et al., 1976).

\section{SUMMARY}

High-resolution sampling of Site 751 has provided an excellent record of variations in the amount of IRD delivered to the Kerguelen Plateau from 9.9 Ma to the present. The oldest IRD found at Site 751 was approximately $9.9 \mathrm{Ma}$, and it was not until approximately 8.5 Ma that significant concentrations of IRD was detected. A major hiatus of $2.4 \mathrm{~m} . \mathrm{y}$. occurred between 8.4 and $6 \mathrm{Ma}$. Changes in ACC flow velocities during the formation of the WAIS may be indirectly related to this erosional event that occurred at Site 751 during the late Miocene.

The first major IRD event encountered at Site 751 occurred in the uppermost Miocene between 6.0 to $5.5 \mathrm{Ma}$ (Fig. 7; Interval B). During this time period, a general climatic cooling and glacial expansion occurred on Antarctica.

A hiatus of $1 \mathrm{~m} . \mathrm{y}$. separates ice-rafting events of the late Miocene and early Pliocene. A continuous episode of elevated IRD deposition occurred in the lowermost Pliocene between 4.5 and 4.1 Ma. The 0.4-m.y. duration and the timing of the
IRD event on the Kerguelen Plateau corresponds with IRD fluxes observed on the Falkland Plateau and in the Weddell Abyssal Plain. This correspondence of data indicates that a major global climatic event occurred during the early Pliocene. The East Antarctic Ice Sheet may have experienced deglaciation between 4.5 and $4.1 \mathrm{Ma}$ and, as a result, released large volumes of sediment-laden ice into the Southern Ocean.

A period of reduced and continuous ice-rafting occurred at Site 751 from about 4 to $3.17 \mathrm{Ma}$, which may reflect a major cooling trend. Continuous and elevated IRD levels occurred in the Pleistocene (1.75-1.6 Ma). Based on stable isotopic records (Shackleton and Kennett, 1975), the IRD occurrence may represent a cooling trend in the Southern Hemisphere.

\section{ACKNOWLEDGMENTS}

The author is indebted to Woody Wise for his helpful discussions and guidance during the preparation of this manuscript. The author is also grateful to Dennis Cassidy and Ami Kaharoeddin of the Antarctic Research Facility (FSU) and Woodward-Clyde Consultants (Tallahassee, FL) for laboratory and drafting/clerical support, respectively. Many thanks are owed to Joanne Hayes and Neill Vaughan (FSU) for laboriously preparing the samples. Bobby Thorton prepared the art work, and Neill Vaughan printed the micrographs. Thanks are also due to Charlotte Kelley, who kindly assisted in editing the manuscript. Special thanks go to my wife, Pamela Breza, for her monumental support during the long months I was away from home at sea and the long hours working in the laboratory. Laboratory support was provided by National Science Foundation Grant DPP-8917976 and USSAC funds. 


\section{REFERENCES}

Anderson, D. M., 1985. Pliocene paleoceanography of the Southern Ocean and the development of the West Antarctic ice sheet [Master's thesis]. San Jose State Univ., San Jose, CA.

Anderson, J. B., 1972. Nearshore glacial-marine deposition from modern sediments of the Weddell Sea. Nature Phys. Sci., 240:189-192.

Blank, R. G., and Margolis, S. V., 1975. Pliocene climatic and glacial history of Antarctica as revealed by southeast Indian Ocean deep-sea cores. Geol. Soc. Am. Bull., 86:1058-1066.

Bornhold, B. D., 1983. Ice-rafted debris in sediments from Leg 71, southwest Atlantic Ocean. In Ludwig, W. J., Krasheninnikov, V. A., et al., Init. Repts. DSDP, 71: Washington (U.S. Govt. Printing Office), 307-316.

Ciesielski, P. F., Ledbetter, M. T., and Ellwood, B. B., 1982. The development of Antarctic glaciation and the Neogene paleoenvironment of the Maurice Ewing Bank. Mar. Geol., 46:1-51.

Ciesielski, P. F., and Weaver, F. M., 1974. Early Pliocene temperature changes in the Antarctic Seas. Geology, 2:511-515.

Ciesielski, P. F. and Wise, S. W., 1977. Geologic history of the Maurice Ewing Bank of the Falkland Plateau (Southwest Atlantic section of the Southern Ocean) based on piston and drill cores. Mar. Geol., 25:175-207.

Denton, G. H., Armstrong, R. L., and Stuiver, M., 1971. The late Cenozoic glacial history of Antarctica. In Turekian, K. K. (Ed.), Late Cenozoic Glacial Ages: New Haven (Yale Univ. Press), 267-306.

Harwood, D. M., 1983. Diatoms from the Sirius Formation, Transantarctic Mountains. Antarc. J. U.S., 18:98-100.

1985. Late Neogene climatic fluctuation in the southern high-latitudes: implications of a warm Pliocene and deglaciated Antarctic continent. S. Afr. J. Sci., 81:239-241.

, 1986. Diatom biostratigraphy and paleoecology with a Cenozoic history of Antarctic ice sheets [Ph.D. dissert.]. Ohio State Univ., Columbus.

Keany, J., Ledbetter, M. T., Watkins, N. D., and Huang, T. C., 1976. Diachronous deposition of ice-rafted debris in sub-antarctic deepsea sediments. Geol. Soc. Am. Bull., 87:873-882.

Kennett, J. P., and Brunner, C. A., 1973. Antarctic late Cenozoic glaciation: evidence for initiation of ice rafting and inferred bottom water activity. Geol. Soc. Am. Bull., 84:2043-2052.

Kent, D., Opdyke, N. D., and Ewing, M., 1971. Climatic change in the North Pacific using ice-rafted detritus as a climatic indicator. Geol. Soc. Am. Bull., 82:2741-2754.

Krinsley, D., and Donahue, J., 1968. Environmental interpretation of sand grain surface features by electron microscopy. Geol. Soc. Am. Bull., 79:743-748.

Loutit, T. S., and Kennett, J. P., 1979. Application of carbon isotope stratigraphy to late Miocene shallow marine sediments, New Zealand. Science, 204:1196-1199.
Margolis, S. V., and Kennett, J. P., 1971. Cenozoic paleoglacial history of Antarctica recorded in subantarctic deep-sea cores. Am. J. Sci., 271:1-36.

Margolis, S. V., and Krinsley, D. H., 1974. Processes of formation and environmental occurrence of microfeatures on detrital quartz grains. Am. J. Sci., 274:449-464.

Miller, K. G., Fairbanks, R. G., and Mountain, G. S., 1987. Tertiary oxygen isotopes synthesis, sea level history, and continental margin erosion. Paleoceanography, 2:1-19.

Osborn, N. I., Ciesielski, P. F., and Ledbetter, M. T., 1983. Disconformities and paleoceanography in the southeast Indian Ocean during the past 5.4 million years. Geol. Soc. Am. Bull., 94:13451358.

Pickard, J., Adamson, D. A., Harwood, D. M., Miller, G. H., Quilty, P. G., and Dell, R. K., 1988. Early Pliocene marine sediments, coastline, and climate of East Antarctica. Geology, 16:158-161.

Schlich, R., Wise, S. W., Jr., et al., 1989. Proc. ODP, Init. Repts., 120: College Station, TX (Ocean Drilling Program).

Shackleton, N. J., 1987. Oxygen isotopes, ice volumes, and sea level. Quat. Sci. Rev., 6:183-190.

Shackleton, N. J., and Kennett, J. P., 1975. Paleotemperature history of the Cenozoic isotope analyses of Antarctic glaciation: oxygen and carbon isotope analyses in DSDP Sites 277, 270, and 281. In Kennett, J. P., Houtz, R. E., et al., Init. Repts. DSDP, 32: Washington (U.S. Govt. Printing Office), 743-755.

Warnke, D. A., 1970. Glacial erosion, ice rafting, and glacial marine sediments: Antarctica and the Southern Ocean. Am. J. Sci., 269:276-294.

Weaver, F. M., 1973. Pliocene paleoclimatic and paleoglacial history of East Antarctica recorded in deep-sea piston cores. Florida State Univ. Sedimentol. Res. Lab: Contrib., 36:142.

1976. Late Miocene and Pliocene radiolarian paleobiogeography and biostratigraphy of the Southern Ocean [Ph.D. dissert.]. Florida State Univ.

Webb, P. N., Harwood, D. M., McKelvey, B. C., Mercer, J. H., and Stott, L. D., et al., 1984. Cenozoic marine sedimentation and ice-volume variation on the East Antarctic craton. Geology, 12:287-291.

Wise, S. W., Gombos, A. M., and Muza, J. P., 1985. Cenozoic evolution of polar water masses, southwest Atlantic Ocean. In Hsü, K. J., and Weissert, H. J. (Eds.), South Atlantic Paleoceanography: Cambridge (Cambridge Univ. Press), 283-324.

Wise, S. W., Jr., and Weaver, F. M., 1974. Chertification of oceanic sediments. In Hsü, K. J., and Jenkyns, H. C. (Eds.), Pelagic Sediments: on Land and under the Sea. Spec. Publ. Int. Assoc. Sedimentol., 1:301-326.

Date of initial receipt: 27 February 1990

Date of acceptance: 14 February 1991

Ms 120B-136 